\title{
Offensive patent portfolio races
}

February 2016

\author{
Accepted for publication in Long Range Planning
}

Florian Jell ${ }^{1,2}$, Joachim Henkel ${ }^{1,3,4}$, Martin W. Wallin ${ }^{5}$

1 Technische Universität München, TUM School of Management, Arcisstr. 21, D-80333 Munich, Germany. Phone: +49-89-289-25741; fax: +49-89-289-25742. Email: florian.jell@wi.tum.de, henkel@wi.tum.de

2 Microsoft Fellow, Program in Law, Economics, and Technology at University of Michigan, Fall 2009

3 Center for Economic Policy Research (CEPR), London

4 Corresponding author

5 Chalmers University of Technology, SE-412 96 Gothenburg, Sweden. Phone: +46 31772 12 31. Email: martin.wallin@chalmers.se

\begin{abstract}
In a patent portfolio race, firms attempt to assemble a large collection of patents. Traditional explanations for patent portfolio races rest on an assumption of fragmented patent ownership where multiple unknown firms employ defensive strategies to forestall holdup. However, patent portfolio races can be observed when patent ownership is concentrated to the hands of a few firms. To explore patent portfolio races under conditions of concentrated ownership we turn to the newspaper printing machine industry, an industry characterized by a few dominant firms. Using multiple sources - patent analysis, archival data, and interviews - we identify antecedents to a phenomenon we label offensive patent portfolio races. Contrary to received wisdom, we find that patent portfolio races can be offensive, aimed at gaining rather than avoiding loss of competitive advantage. Offensive patent portfolio races hinge on the breakdown of cooperation - triggered by changes in the perceived benefits, effectiveness, and/or costs of patents, partly mediated by the adoption of a gain frame towards increased patenting, and regulated by the potential losses from further increases. We explain the behavior by invoking the folk theorem in game theory and conclude that while triggering offensive patent portfolio races may yield temporary advantages, managers are advised to tread carefully as offensive patent portfolio races may have severe implications for the effectiveness and efficiency of the innovation process.
\end{abstract}

Keywords: Patent strategy, motives to patent, intellectual property, patent thickets

Acknowledgments: The authors are especially grateful to Rosemarie Ziedonis, Arvids Ziedonis, Rebecca Eisenberg, Dietmar Harhoff, and members of the strategy department at Stephen M. Ross School of Business for providing valuable comments on our study. We are indebted to the Editor of Long Range Planning, Gianvito Lanzolla, and two anonymous referees for numerous suggestions that greatly improved the paper. We furthermore thank participants at various conferences for valuable comments. 


\section{Introduction}

Patenting rates have increased considerably over the last decades (Hall, 2005). Explanations range from institutional changes that have benefited patent holders to changes in how firms manage R\&D (Kortum and Lerner, 1999). In some industries, patenting increases take the form of patent portfolio races in which firms compete to assemble the greatest collection of patents. ${ }^{1}$ They do so in an effort to reduce the threat of being held up by other patent owners, the rationale being that a larger patent portfolio comes with a greater ability to countersue a potential plaintiff (Cohen et al., 2000; Hall and Ziedonis, 2001; Ziedonis 2004). In other words, these measures are largely defensive - patents are not obtained with the purpose to gain market share or increase profits but to defend against potential aggressive competitors.

In this paper, we investigate and theorize a different kind of portfolio race: the offensive patent portfolio race. Our interest is sparked by an anomaly between patenting literature and empirical observations. Received literature has explained patent portfolio races to occur because of fragmented ownership of patents. The logic is straightforward: High fragmentation, with possibly thousands of patentees, decreases the odds of identifying the holders of all relevant patents prior to designing and manufacturing a product (Hall and Ziedonis; 2001, Williamson, 1985; Ziedonis, 2004) and increases the risk of patent infringement by the focal firm. As a result, firms amass defensive patents to mitigate the risk of rent expropriation in case of holdup. While the argument is appealing, convincing and in many cases fitting, it is troubled by an itching observation: patent portfolio races also occur when patent ownership is concentrated to the hands of a few firms - a situation where the need for defensive patents ought to be lower. To explore this puzzling observation we turn to the newspaper printing machine industry, an industry that experienced a patent portfolio race despite being a tight oligopoly. Relying on patent analysis, archival data and expert interviews we demonstrate that patent

1 Patent portfolio races must be distinguished from patent races. In a patent race, firms compete to be the first to achieve a specific invention and to obtain a patent on it (cf. Dasgupta and Stiglitz, 1980; Loury, 1979; Reinganum, 1982). In a patent arms race, in contrast, firms compete for the largest patent portfolio. There are parallels between the two phenomena with respect to the participants' incentives, which in both cases relate to building a competitive advantage based on intellectual property rights. However, in a patent race this advantage would come from the exclusionary power of a single patent, while in a patent portfolio race it would be based on that of a large portfolio. Also, a patent race has a unique winner, while a patent portfolio race has a continuum of possible outcomes including symmetric situations. Given the importance of individual inventions in discrete technologies, a patent race should be more likely in such a setting, while a patent portfolio race appears more plausible in complex technologies such as the one we study. 
portfolio races can have an offensive purpose directed towards gaining market share and increasing profits rather than a defensive purpose. In particular, we find that starting from a cooperative situation of stable patenting rates the first mover adopted a gain frame towards increased patenting, partially triggered by the introduction of broader printing cylinders. While this innovation did not pose serious technical challenges, it did create opportunities for filing more patents, in particular on combinations of known inventions with the new cylinder width. The first mover's growing patent portfolio then prompted the second mover to follow suit. A patent portfolio race, or "arms race" ensued. To make our point, we rule out alternative explanations of the explosive increase in patenting.

This article is organized as follows. In the next section we discuss extant literature on antecedents to patent portfolio races. We then describe data collection and analysis, followed by a presentation of our results. In the final sections, we conclude and discuss implications for research, policy and managers.

\section{Antecedents to patent portfolio races}

In discussing known antecedents to patent portfolio races we highlight three points. First, when ownership of intellectual property (IP) is fragmented firms expand their patenting to avoid holdup problems. Second, when IP ownership is concentrated ex ante solutions to holdup are generally feasible. Third, even with concentrated IP ownership firm may deviate from stable patenting rates for a number of possible reasons.

\section{High levels of patenting in fragmented markets: Avoiding holdup}

The ownership of IP is highly fragmented in industries such as semiconductors, electronics, and software. ${ }^{2}$ In the semiconductor industry potential rights holders range from nonpracticing entities over pure design firms to integrated manufacturers (Arora et al., 2001, p. 76; Macher et al., 1999; Ziedonis, 2003). In his testimony before the U.S. Federal Trade commission in 2002 Peter N. Detkin of Intel Corporation estimated that more than 10,000

2 Arora et al. (2001) and other authors speak of fragmented markets for technology. Since we are mainly interested in the fragmentation of IP ownership, and since fragmented (or concentrated) IP ownership does not necessarily imply a fragmented (or concentrated) market for technology (because there may not be any trade in IP and thus no true market for technology), we focus on the degree of fragmentation of IP ownership. 
parties held the approximately 90,000 existing patents for central processing units. ${ }^{3}$ The situation is similar in the communication electronics industry where Gilroy and D'Amato (2009) estimate that over 2,700 separate entities were actively patenting technology relevant to the fourth generation of cellular wireless networks and devices in 2008.

In such a situation, firms amass defensive patents in order to mitigate holdup risk and forearm against infringement suits (Cohen et al., 2000; Hall and Ziedonis, 2001; Ziedonis, 2004). The rationale of this strategy is the ability to countersue potential plaintiffs, at least those that are practicing entities themselves (in contrast to "nonpracticing entities", or "patent trolls"; e.g. Lemley and Shapiro, 2007; Reitzig et al., 2007). Firms resort to such defensive measures because they are generally unable to arrange ex-ante licensing due to transaction costs, in particular the costs of identifying a large number of unknown patent holders and of closing licensing deals with them. Moreover, fragmentation of patent ownership increases the risk of patent infringement because it complicates patent monitoring. And finally, infringement will often be discovered only after the firm has made significant investments in development and production, when inventing around the infringed patent is inadequately costly and the infringer thus in a particularly weak position.

This link between IP fragmentation and higher patenting rates has broad empirical support. Hall and Ziedonis (2001), analyzing a sample of 95 publicly traded semiconductor firms over a period of 10 years, report a doubling of patent output per R\&D dollar and conclude that firms entered patent portfolio races in order to forearm against holdup by competitors that owned patents required for the firms' own production. Ziedonis (2004), studying 67 semiconductor firms, finds that a wide distribution of patent rights leads to more aggressive patenting by capital intensive firms, the rationale being that holdup would hit these firms particularly hard due to idle production capacity. Cockburn and MacGarvie (2009), based on an analysis of 27 distinct software product markets between 1980 and 2006, find evidence that firms without patents are less likely to go public if they operate in a market characterized by overlapping IP rights (so called "patent thickets"; Shapiro, 2001). This creates an incentive for firms owning fewer patents in "thicket-markets" to increase their patent portfolios in order to improve their chances of going public. Noel and Schankerman (2006), using panel data on

3 Peter N. Detkin, vice president, Legal and Government Affairs and assistant general counsel, Intel Corporation, 28 February 2002, http://www.ftc.gov/sites/default/files/documents/public_events/competition-ip-lawpolicy-knowledge-based-economy-hearings/020228ftc.pdf (accessed 03/08/2014). 
software firms in the United States during 1980 to 1999, find that higher fragmentation of patent rights is associated with higher patenting activity.

\section{Moderate patenting in concentrated markets: Ex ante solutions to holdup}

The situation is entirely different when IP ownership is concentrated. Holdup risk due to inadvertent patent infringement is lower since firms do not have to fear litigation by previously unknown patent holders - as all players are known. Firms can more easily implement cross-licensing agreements to resolve or avoid situations of escalating patenting (Shapiro, 2001). Furthermore, due to the small number of relevant patent holders it is feasible to monitor their patent applications. In particular, this implies that a first mover in a patent portfolio race must anticipate retaliation and thus has less of an incentive to initiate a race in the first place. Thus, the explanations of patent portfolio races brought forth in the context of fragmented IP ownership hardly apply. In line with Noel and Schankerman (2006) one would expect that the mitigation of holdup risk is less important as a driver of patenting activity in concentrated markets.

The anticipation of retaliation requires some additional considerations. Needless to say, patent infringement occurs also in concentrated industries, for one reason because patents do not properly fulfill their "notice function" (Bessen and Meurer, 2008). Thus, a firm that fears it will infringe on a competitor's patents may increase its own patenting in order to forearm against infringement litigation (Hall and Ziedonis, 2001; Lanjouw and Lerner, 2001; von Hippel, 1988, p. 53). However, what follows is different from the fragmented situation. In many respects it resembles an oligopolistic price war: As the first mover (in this case the potential infringer) increases its patenting, followers (competitors) respond swiftly and forcefully because they - correctly - perceive the first mover's increase in patenting as directed towards them. In other words, in concentrated industries, strategic interactions between firms are direct as the identity and actions are known to all players (Porter 1980, p. 91). As a result, firms can anticipate these reactions and are likely to prefer a cheaper cooperative solution over attempting to forestall holdup through expensive increases in patenting rates.

\section{Expanding patenting in concentrated markets: Possible reasons}

From the above it should be clear that, if a patent portfolio race develops in a concentrated market, then the behavior of the second mover is a reaction to that of the first mover. However, it is less obvious what could trigger the first mover to deviate from hitherto stable pa- 
tenting rates. We address this question in the following, focusing on changes in the benefits, effectiveness, and costs of patents.

\section{Changes in the benefits of patents}

Firms can be expected to increase their patenting if any of the various reasons to patent become more important. We discuss each reason in turn.

Preventing imitation and blocking competitors are among the most important reasons to file patents (Cohen et al., 2000; Levin et al., 1987; Sattler, 2003). Either can change in importance when the intensity of competition in the respective industry changes. This may happen, e.g., due to shifts in demand, the introduction of new production or distribution technologies, or market exit and entry. Even the threat of new market entry might trigger incumbents to increase patenting, since patents may work as market entry barriers (Bain, 1956; Caves, 1974; Caves et al., 1991; Porter, 1980; Rabino and Enayati, 1995).

Deterrence of litigation and the need for cross-licensing are important patenting motives in particular in complex technologies. Thus, when other IP holders increasingly enforce their patents against the focal firm, a growing need for patents arises (Grindley and Teece, 1997). The firm would defensively file more patents for the purposes of retaliation and bargaining, and thus to forearm against expropriation.

An increased emphasis on licensing revenue may be a further trigger to increase patenting. Since it is more difficult to invent around a larger patent portfolio, broader patenting increases the odds of receiving royalties. Also, a larger portfolio typically allows its holder to charge higher royalties. Such an increased focus on licensing and thus on patenting may even have been triggered by the management literature (e.g. Reitzig, 2004a, 2007; Rivette and Kline, 2000a, b). A prominent example is Texas Instruments, a firm that faced severe income problems in the mid-1980's and as a result turned to using patents for generating licensing revenues (Grindley and Teece, 1997; Hall and Ziedonis 2001).

Regarding the reputational function of patents, if the management board adopts the view that high numbers of patent applications signal technology leadership to customers or investors, then this firm would ramp up its patenting. Such a firm has "[...] an incentive to produce the indicator rather than what it is supposed to indicate" (Macdonald 2001, 2004, p. 145). The usage of patents to improve a firm's reputation has been empirically shown by Blind et al. (2006) and Ramani and Kumar (2008) and, with a focus on venture capital financing, by Hsu and Ziedonis (2013) and Hoenen et al. (2014). 


\section{Changes in the effectiveness of patents}

Also changes in the effectiveness of patents may lead a firm to adjust its patenting. The direction of this adjustment is not clear ex ante: reduced effectiveness may imply that weaker applications are no longer worth filing; or, alternatively, that in order to attain the desired level of protection a larger number of patents is needed.

Interestingly, the latter outcome seems to prevail. Individual patents are perceived as relatively ineffective in most industries and in particular in complex technologies (Arundel, 2001; Cohen et al., 2000; Levin et al., 1987; Mansfield, 1986; Sattler, 2003), for one reason because they can often be invented around (Cohen et al., 2000). As a remedy, firms build "patent fences" (Guellec and van Pottelsberghe, 2007, p. 87; Reitzig, 2004b) by patenting not only the initial invention but also variations such as different geometric shapes (Granstrand, 1999, p. 220). Jointly these patents, and even pending applications, make it costlier to invent around, and they sometimes even block competitors (Granstrand, 1999; Cohen et al., 2000; Kash and Kingston, 2001; Arundel and Patel, 2003; Blind et al., 2009; Jell et al., 2013).

The above argument applies to most uses of patents, in particular to preventing imitation and blocking competitors. It applies least to the reputational function, where patent numbers matter more than their reliability as exclusion rights. The effectiveness of patents in enhancing a firm's reputation changes with the perception of the respective stakeholders. While patents used to be the domain of technical and legal specialists a few decades ago, they now play an important role in demonstrating a firm's innovativeness to outsiders, and so their effectiveness as a means to build reputation has increased.

Also increasing opposition rates ${ }^{4}$ can be seen as reducing the effectiveness of patent applications, by reducing the average probability that the patent will be granted and upheld. As a result, they may create incentives to pursue a multiple-patents strategy (cf. Harhoff and Hall, 2002; Harhoff and Reitzig, 2004). Since preparing an opposition proceeding is far more laborintensive and costly than filing a patent, firms can mitigate the risk of losing patents through opposition by filing more patents on the same invention, or more patents in general.

4 At the European Patent Office and the German Patent and Trademark Office, third parties may file an opposition against a granted patent within nine months after the grant. 


\section{Changes in the cost of patents}

Changes in patenting standards and other system level factors influence the costs of procuring and enforcing patents, and thus the propensity to patent. These costs comprise monetary costs as well as transaction costs and other efforts related to patents. Hall (2005) discusses whether major changes in the U.S. patent system, such as the creation of the Court of Appeals for the Federal Circuit have led to increases in the propensity to patent. Also the grant policies of patent offices may have influenced this increase. For example, Wagner (2008) reports a de-facto liberalization of grant policies at the European Patent Office (EPO) which, albeit prohibited by the European Patent Convention (Article 52(2)), granted patents on business methods. If grant policies become more liberal, a firm may realize at some point that inventions hitherto not patentable now can successfully be pushed through the patenting process. It may adopt this practice and henceforth increasingly patent such inventions (Merges, 1999).

Procuring patents may also become easier when technological developments create opportunities for patenting. Technological breakthroughs in particular may trigger a surge of patent applications (e.g., Ahuja et al., 2005). Even if some of the underlying inventions are obvious, they may pass the inventive step test (since there is little prior art in the patent databases), thus allowing the first mover to get a head start in a portfolio race.

To conclude, there are a number of reasons why firms in concentrated industries would unilaterally increase their patenting, thus potentially triggering patent portfolio races. The resulting type of race is different from defensive patent portfolio races in at least two regards. First, first movers should have strong incentives not to deviate from stable patenting rates since - as suggested by the folk theorem (e.g., Tirole, 1988) - aggressive actions may provoke retaliation by followers and result in a new equilibrium with higher cost for both. Under these conditions firms are most often better off not "rocking the boat." Second, in defensive races firms are plentiful and generally unknown to each other, making it difficult to police behavior and discipline firms that deviate from stable patenting rates. This is not the case in offensive patent portfolio races, where each firm's patent build-up is directed towards known rather than unknown competitors - i.e. where strategic interactions are direct.

\section{Research question}

The literature review identified an anomaly between explanations for patent portfolio races and empirical observations. Conventional wisdom suggests that patent portfolio races will ensue as firms expand their patenting in a defensive effort to forestall holdup. Surprisingly 
little, however, is known about the antecedents and mechanics of patent portfolio races when IP ownership is concentrated. Theory would generally predict that firms would avoid a costly arms race when alternative mechanisms (e.g., cross-licensing) are at hand to avoid losses from unintentional infringement. Yet, there are anecdotal accounts of patent portfolio races in concentrated industries. We thus ask: what are the antecedents and mechanics of patent portfolio races when IP ownership is concentrated?

\section{Research design and setting}

\section{Sample and research setting}

To explore our research question we turn to the German newspaper printing machine industry. We do so for three reasons: its high degree of market concentration, its highly concentrated patent ownership, and a dramatic increase in patenting in the late 1990s.

Market concentration: The global industry for newspaper printing machines is a highly concentrated oligopoly. As of 2007, the four largest firms account for nearly 90 percent of sales. ${ }^{5}$ Since its emergence in the late nineteenth century the industry has undergone a process of consolidation to become dominated by only four manufactures. Europe - and especially Germany - dominates the industry. The German companies Manroland AG and Koenig \& Bauer AG (KBA) have a market share of $28 \%$ each. The U.S. company Goss International Inc. has an $18 \%$ market share, and WIFAG Maschinenfabrik headquartered in Switzerland trails at 13\%. To underscore Europe's dominance, although headquartered in the US, Goss performs a significant share of their manufacturing and development in Europe. ${ }^{6}$

Concentration of patent ownership is equally high in this industry (see Appendix, e.g. Ziedonis' fragmentation index). This is mostly a consequence of the high concentration of the product market, supported by a high degree of product specificity (newspaper printing machines, or parts thereof, are unlikely to be used by firms other than newspaper publishing

5 Worldwide market volume in 2007 is estimated at EUR 1.0 to 1.2 billion with the following market shares: Koenig \& Bauer: 28 \%; Manroland: $28 \%$; Goss: $18 \%$; WIFAG: $13 \%$; Source: KBA: http://www.kbaprint.de/Filestore.aspx/aktuelle kba-pr\%C3\%A4sentation.pdf?pool=kba\&type=file\&key=eea40870-d11c49c6-901e-221137189c41\&lang=en\&filetype=pdf\&index=true (accessed 08/16/2012). We identified major players in the oligopoly on the basis of market research provided by Manroland and KBA. In our interviews, we asked in a separate question if we missed relevant players. We cross-checked our list with findings from database research (e.g. Compustat, ThomsonOne, Exhibitors list of printing trade fair DRUPA 2008). 
houses) and high vertical integration of manufacturers (for example, Manroland even operated its own steel foundry $)^{7}$. High levels of vertical integration increase the likelihood that relevant patents are held by manufacturers, instead of multiple suppliers or industry outsiders.

The high degree of concentration is evidenced by opposition proceedings at the EPO involving KBA, Manroland, or both. ${ }^{8}$ In each case, the respective other firm is by far the most important opponent. For example, of the 89 oppositions filed against patents granted to KBA, 57 were filed by Manroland, 17 by WIFAG, 13 by Heidelberger, and five by Goss (some were filed by more than one party). Only three did not come from one of the large printing machine makers. Similarly, 11 of the 16 oppositions against Manroland came from KBA, all others from Goss, WIFAG, and Heidelberger. In turn, 22 of KBA's 61 oppositions were aimed at Manroland, and 32 of Manroland's 46 oppositions at KBA. These numbers support the notion of a rather concentrated IP ownership. The strong concentration of IP ownership is underscored by an IP manager who explained:

(a) "[...] in the patent landscape of printing machines, particularly rotary printing presses", no fragmentation takes place. Rather, there are always the same market players who file patents or try to enforce granted property rights against competitors." (IP Manager)

Dramatic increase in patenting: Fig. 1 shows the numbers of EPO patent applications of all four firms in the industry between 1992 and 2006. The diagram contains only applications pertaining to newspaper printing machines.10 An overview of all patent applications (i.e. in-

7 http://www.manroland.com/com/en/Products_Services_Manufacturing_Services_Foundry_patternmaking.htm (accessed 08/16/2012).

8 We downloaded information about the EPO opposition proceedings from the Darts-IP database on 19 February, 2014. We obtained information covering the time period 2008 to 2013. While this period dates after the period we focus on, the degree of industry concentration reflected in the concentration of the plaintiffs and defendants is also informative for earlier years due to rather low industry dynamics.

9 Rotary printing presses is a technical term for newspaper printing machines.

10 Both KBA and Manroland also produce printing machines unrelated to newspaper production. We excluded the respective patent applications from our analysis. Since the International Patent Classification system does not separate newspaper printing machines from other printing machines (most patents are classified in B41F, "printing machines or presses"), we employed an algorithm based on geographical matching. We used the postal code of each first inventor indicated on a patent application and matched it to the companies' sites. Since for both companies facilities related to newspaper printing machines are at different and geographically distant locations than those related to other products, we can use this method to exclude nonrelevant patents. Less than 5 percent of the patent applications classified as relevant by this method have a second or further inventor from a facility related to other products, so that our classification should be correct in nearly all cas- 
cluding patent applications pertaining to sectors other than newspaper printing machines) of the four firms at the US Patent Office, the German Patent and Trademark Office (GPTO), the EPO and via the PCT process can be found in the Appendix.

\section{--- Insert Figure 1 here ---}

Fig. 1 reveals a striking pattern. Before 1999, patenting by all four firms is on a stable level with only minor fluctuations. However, between 1999 and 2002 KBA increased their patenting by almost four times. Similarly, Manroland experienced an increase by a factor of 2.6 between 2004 and 2006. If Manroland's increase is indeed a reaction to KBA's (as in a patent portfolio race), the time lag between the two events is not surprising. Since patent applications are not published until 18 months after the filing date, there is a natural lag between an increase in patenting and it being observed by competitors. In addition, competitors need time to ramp up their own patenting. We would also assume a further year to lapse until Manroland realized that the increase is sustainable and not a singular outlier. These reasons jointly prompt us to select the German newspaper printing machine industry to investigate our research question.

\section{Data collection}

To the best of our knowledge no evidence on the detailed antecedents and mechanics of patent arms races in concentrated markets exists. We opt for an exploratory case design, which allows us to investigate a phenomenon (patent portfolio races) in a bounded context (the newspaper printing press industry) (Miles and Huberman, 1984). Following the work by Hall and Ziedonis (2001) on patent portfolio races in the U.S. semiconductor industry we rely on a mix of field interviews and archival data (for an overview of data sources see table in the Appendix). Our initial investigation targeted the four largest firms that accounted for almost

es. In the case of WIFAG and Goss, we included all patent applications because both firms build exclusively rotary printing machines. Industry matching as recommended in OECD Patent Statistics Manual (2009) and by Schmoch et al. (2003) was not feasible in our case. For example, Schmoch et al. (2003) link IPC code B41F (which contains relevant patents and also non-relevant patents) to NACE code 29.5 (special purpose machinery), which contains many non-printing machines sectors. For the required NACE code on the second-next level, e.g. 29.56.1 (web-fed printing machines) no matching with relevant IPC classes is available. 
90 percent of the market. Later we honed in on two firms for a more detailed analysis: KBA and Manroland that most clearly engaged in a patent portfolio race.

We use data from the Worldwide Patent Statistical Database (PATSTAT) and patent process information from the International Patent Documentation Center (INPADOC) between 1992 and $2006^{11}$ in order to identify and analyze the development of patent portfolios in the industry. We also collected press articles (e.g. from LexisNexis), financial data (e.g. from Compustat and Thomson/Reuters), and annual reports of printing press manufacturers. The collection of archival data has two purposes: to capture patenting behavior and to allow for triangulation with interview data (Eisenhardt, 1989; Yin, 2003, p. 14; Shah and Corley, 2006). Between the end of 2007 and early 2009 we conducted 23 field interviews (listed in the Appendix). The qualitative interviews allowed us to explore the essential antecedents and mechanics of patent arms races under conditions of concentrated IP ownership.

In particular, we conducted eight in-depth interviews with patent and R\&D executives of printing machine manufacturers. We asked about patenting related trends in their industry as well as about their own and their competitors' patenting behaviors. One advantage of retrospective interviews is that respondents may reveal insights they otherwise would not be prepared to share (Jenkins, 2014). These interviews were complemented by email exchanges and follow-up interviews, allowing us to ask clarifying questions and to obtain feedback on drafts of the paper. We also conducted 15 complementary interviews - with a patent examiner at the EPO, a specialist from the printing department at the German Engineering Federation $(\text { VDMA })^{12}$, four CTOs of newspaper publishing companies, and nine industry experts interviewed at the DRUPA 2008 printing trade fair in June 2008. ${ }^{13}$ The latter were product managers, $R \& D$ engineers, sales managers, or executives of manufacturers of printing machines. These complementary interviews corroborated the selection of KBA and Manroland as the

11 We use an April 2009 version of PATSTAT. This version includes patent applications published until early 2009. Since there is a delay of 18 months before a patent application is made public, the first full year of observation is 2006.

12 VDMA stands for "Verband Deutscher Maschinen- und Anlagenbau" (in English: German Engineering Federation). It is the largest engineering industry network in Europe. http://www.vdma.org/en/der-vdma (accessed 03/09/2014).

13 DRUPA stands for "Druck und Papier" (in English: Print and Paper). It is the world's largest trade fair in the printing industry. http://www.drupa.de/ (accessed 03/09/2014). 
key firms for our study. They also indicated that firms used patents in a quite offensive manner.

Our eight key interviews and three further interviews, with an average duration of 45 minutes, were recorded and transcribed. Twelve interviews, lasting on average 30 minutes, could not be recorded due to reasons of confidentiality so that handwritten notes were taken.

\section{Data analysis}

The analysis of all documented material follows the approach of qualitative content analysis (Mayring, 2004) and was performed using the NVivo 8 software package. Specifically, we investigated the patenting behavior of KBA and Manroland, focusing on the reasons for defecting from stable patenting rates. We first coded the data according to categories such as 'patenting' motives', 'patenting strategy', 'patenting increase' and 'patent system', and recognized the importance of changes in the cost and benefits of patents (for a similar approach see e.g., Messeni Petruzzelli and Savino, 2014). Subsequently, we searched for a relationship between such changes and increases in patenting, resulting in a preliminary model of the antecedents and mechanics of patent portfolio races. Finally, following Eisenhardt (1989) we refined the model, iterating between primary data, emerging constructs and the literature on game theory and patent portfolio races to arrive at the model depicted in Fig. 4. To eliminate bias from retrospective interviews we used triangulation of data (patent data, interviews, other documents). This approach allowed us to cross check interviewee responses either with responses of other interviewees from the same company or with other data sources. In cases where we believed that responses had a retrospective bias, we contacted our interviewees again and discussed the respective point.

\section{Results: Evidence and triggers of a patent portfolio race}

We present our results in five sections. First, we establish the presence of a patent portfolio race and identify the players. Second, we describe the race between its two contestants: KBA and Manroland. Third, we rule out alternative explanations of the elevated patenting rates. Fourth, we analyze arms race triggers and specifically ask what prompted KBA to deviate from stable patenting rates. Finally, we discuss changes in patent filing strategy by which $\mathrm{KBA}$, and Manroland in response, effectuated the increase in patenting. 


\section{Participants in the arms race}

Recall that we selected the newspaper printing press industry because we had good reasons to believe the industry had experienced a patent portfolio race. Further recall that in a patent portfolio race firms behave like nations in an arms race: They try to assemble the greatest arsenal - here the arsenal consists of patents. Such races can have multiple players, but two are enough. Below we will provide evidence that indeed a patent portfolio race ensued between two firms: KBA and Manroland. Patenting in these firms grew independently of the firms' size, inputs to R\&D and innovative output, nor was it the result of collusive behavior. Neither Goss nor WIFAG participated in the race.

Fig. 1 provides some initial evidence of a patent portfolio race. There are substantial increases in patenting by KBA after 1999, by Goss after 2003 and by Manroland after 2004. In the case of WIFAG, no increase in patenting is observed. This is due to WIFAG's less aggressive IP policy, which relies on securing freedom to operate through prior use defense rather than through growing the patent portfolio. This strategy appears sensible since WIFAG, due to its smaller size (around 1,400 employees, of those around 200 in engineering) ${ }^{14}$, would likely not have been able to compete in a patent arms race with its far bigger competitors Manroland and KBA (both more than 8,000 employees; more than 800 in R\&D, cf. Table 1). Moreover, WIFAG believed they were small enough to fly under the radar; also, in terms of geographic market they were competing less directly with the big players than those among each other. In the case of Goss, there is conclusive evidence that the increase in its patenting is due to the expansion of the firm rather than to a strategic increase in patent output. Goss's patenting increase since 2004 is due to a major acquisition of a business line from Heidelberger Druckmaschinen AG in 2004. An analysis of Goss's patent applications reveals that 83 percent of the applications filed after 2003 originated from business units that were part of that transaction. ${ }^{15}$

14 See corporate Web site: http://www.wifag.ch/cmse/index.php?id=43,0,0,1,0,0 (accessed 05/18/2010) or, in German, http://de.wikipedia.org/wiki/WIFAG_Maschinenfabrik_AG (accessed 03/14/ 2014).

15 E.g. facilities located in Dover (NH, USA), Boxmeer (Netherlands), or Montataire (France). Goss acquired the web-fed offset business of Heidelberger Druckmaschinen AG in 2004. http://connection.ebscohost.com/c/ articles/14142561/heidelberg-goss-finalize-web-systems-transfer-agreement (accessed 03/14/2014). 


\section{The race between KBA and Manroland}

We now demonstrate how KBA greatly increased its patenting and Manroland followed suit, reporting the result from a patent analysis of these two firms. We limit the analysis to patents valid in Germany, for two reasons. First, the firms share Germany as their common home market; and second, both are mostly producing in Germany (which matters since a patent covers products sold as well as products produced in the respective country). That is, we include patent applications filed at and granted by the EPO that indicate Germany as a designated state of protection (Fig. 2), and patent applications that were filed directly at and granted by the GPTO (Fig. 3). For granted patents, we extracted from our database grant dates and expiration dates (through nonpayment of renewal fees, withdrawal, or 20 years after filing). Using this information, we calculated the stock of granted, active patents in each firm's portfolio that relate to newspaper printing presses. In the patent stock, we took into account patents (related to newspaper printing presses) that were acquired through M\&A activity. ${ }^{16}$

Fig. 2 reveals a startling pattern. Whereas Manroland has a rather stable portfolio of EPO-granted German patents, KBA seems to have pursued a much more aggressive policy. KBA's dramatic increase in patenting after 1999 leads to a strong growth of its patent portfolio in the subsequent years. While KBA held fewer EPO-granted patents than Manroland in 1997, its portfolio of such patents is almost three times as large as Manroland's in 2005. Manroland, in contrast, holds a portfolio of rather constant size, with around 140 EPO-granted German patents between 2000 and 2006. Due to grant lag, we do not yet observe the impact of Manroland's more than doubling of EPO patent applications in 2005.

\section{--- Insert Fig. 2 here ---}

In Fig. 3, we present the results of an analogous analysis of patent applications filed directly at the GPTO. This diagram shows very clearly when the two firms abandoned their strategy of stable patent portfolios. While both firms' portfolios of GPTO-granted patents had a stable size of around 150 patents between 1992 and 2001, KBA's hike in patent application numbers, from 39 in 1999 to 105 in 2000, leads to a continuous growth of its portfolio in the

16 Specifically, we took the acquisition of Albert-Frankenthal AG (a manufacturer of rotary printing presses) by KBA in 1988 into account. This acquisition happened long before the patent portfolio race. During the race, as explained, there was no acquisition that contributed to the growth in patent applications (nor to that in patents). 
subsequent years. In 2006, it is more than twice as large as in 2000. A reaction by Manroland is observed in 2004, with patenting rates more than tripling from 26 in 2003 to 91 in 2004. We observe the beginning of an increase in portfolio size in 2005.

--- Insert Fig. 3 here ---

It is noteworthy that Manroland's first reaction is stronger at the GPTO (91 applications in 2004, up by $250 \%$ from 26 in 2003) than at the EPO (48 applications in 2004, up by $167 \%$ from 18 in 2003). Patent applications being less costly at the GPTO makes it is easier to effectuate a strong increase nationally. At the same time, GPTO patents are equally effective as EPO-granted patents in the bilateral relationship of Manroland and KBA, since both firms manufacture in Germany and patents can also be used to forbid production of infringing goods. The further increase in GPTO patenting (by 33 percent) by KBA in 2006 can be explained similarly. If patents are primarily used in the bilateral relationship, it is sensible for KBA to react to Manroland's increase by increasing patenting at the GPTO, a fact that would also explain the decrease in KBA's EPO patenting in 2006 (Figure 2). Since EPO patenting is more costly and KBA's application rates have been about three times as high as Manroland's in the past, it is plausible that KBA substituted equally effective, less costly GPTO patent applications for at least some of its EPO patent applications. These results suggest that KBA and Manroland were indeed engaged in a bilateral patent portfolio race. Unprompted, an IP manager at Manroland likened this relationship to an arms race:

(b) ,, [...] a typical arms race occurred. One party dashes away, starts threatening you, you feel threatened, you get hit, then you follow. Finally you stand vis-à-vis bristling with weapons and then both parties realize: no one can really act without the other [...]." (IP Manager)

Another interviewee elaborated on how Manroland responded:

(c) "Our strategy today is that we, too, increasingly file patents. [...] With several purposes: First, in order not to be blocked in important areas [...] Second, in order to have material to negotiate in similar situations not about licensing, but about exchanging patents. " $R \& D$ Manager)

We summarize our findings so far in our first proposition. 
Proposition 1. In an industry with concentrated patent ownership, a significant increase in patenting output by one firm triggers a response in kind by those firms that perceive the increase as a competitive threat, leading to a breakdown of the implicit cooperation that kept patenting at stable rates.

\section{Alternative explanations to the race}

To be conclusive, we now rule out alternative explanations. Using data from Thomson/Reuters and from our interviews, we can first rule out that mergers or acquisitions caused the increase in patenting. ${ }^{17}$ Second, growth with the average can be excluded. The dramatic increases in KBA's and Manroland's application numbers are far above average growth rates (about $3.7 \%$ at the EPO) ${ }^{18}$. Also, patenting by Manroland and KBA increased sharply and $a d$ hoc rather than continuously. Third, we can exclude that increases in $R \& D$ inputs played a significant role in explaining the observed surge in patenting. Interviewees dismissed this explanation, and also data on $R \& D$ expenses from annual reports, while incomplete, show no increases that would explain the more than doubling of patenting by both firms. ${ }^{19}$ Even more striking evidence is provided by $R \& D$ headcount numbers (Table 1). In the case of KBA, we observe a slight increase in R\&D headcount between 1998 and 2002 (by 155 employees or 21 percent), but by far not a quadrupling. The pattern is even more striking for Manroland: while patenting increased more than three-fold between 2002 and 2005, R\&D headcount decreased steadily between 2001 and 2004, by 282 employees or 24 percent.

\section{--- Insert Table 1 here ---}

Fourth, in order to evaluate a potential increase in innovative output, we analyzed product portfolios of Manroland and KBA. The search does not reveal a tremendous increase in new product introductions during the period of the patenting explosion (we will address the particular case of new broader printing cylinders later). These findings are supported by interview

17 For KBA, a minor acquisition took place in 2001 (De La Rue Giori SA), which is unrelated to newspaper printing. In the case of Manroland, three small firms were acquired after 2001, which had filed no patent applications before the acquisition.

18 Between 1982 and 2002; cf. EPO (2007: 36).

19 Data was taken from the full text of annual reports since most of the companies do not report R\&D expenses in the income statement. 
evidence. Since responses by manufacturing firm representatives would likely be biased, we asked users of newspaper printing machines. None of the four interviewees saw any relation between the respective manufacturers' innovativeness and the number of their patent filings. In fact, WIFAG, the firm with the lowest number of patent applications in the sample, is perceived at least as innovative as KBA, Manroland, and Goss. The CTO of a large German newspaper publisher stated:

(d) "[...] from my perspective all of them are very active in patenting, but none of them had a real blockbuster product. [...] I would say WIFAG was the most innovative firm in the past [...]." (Chief Technology Officer)

Fifth and finally, collusive behavior might provide a potential explanation. It would be present if KBA and Manroland had jointly increased their patenting to erect market entry barriers for new entrants or to squeeze out competitors such as WIFAG. Our interviewees acknowledged that blocked market entry and increased pressure on third parties might be side effects of the portfolio race. However, they made clear that it was not the motive to initiate or join the race. One interviewee commented:

(e) 'At the end it might be that you don't win against your strongest enemy, but against the rest of the world. We have thought of this outcome, [...] but we do not observe that it is happening." (IP Manager)

Incumbents not involved in the race supported this view. The interviewees (e.g. IP Manager from WIFAG and General Manager from Goss) did not perceive KBA's and Manroland's increase in patenting as a joint strike against them, but rather as a fight between the two market leaders. For example, the IP Manager at WIFAG explained that:

(f) "Of course they are more aggressive, presumably against each other. Manroland and KBA focus much more on each other than on us. We are rather small among the big players [...]" (IP Manager)

The interpretation that the patenting increase did not have the purpose of erecting market entry barriers is further supported by the view, expressed by several interviewees, that in this industry product complexity constitutes a far more effective entry barrier than patents. 


\section{Antecedents to the race: Why KBA increased patenting}

Having established that KBA and Manroland were engaged in a patent portfolio race, we now analyze the drivers that induced KBA to start the race. Following the structure laid out in our literature review, we address changes in the benefits, effectiveness, and costs of patents.

\section{Changes in the benefits of patents}

Of the various reasons to patent that we discussed above, blocking, generating licensing revenue, and cross-licensing seem to have increased in importance for KBA. ${ }^{20}$

Blocking its main competitor gained importance for KBA at least temporarily. One interviewee commented on the effects of KBA's strategy:

(g) "[...] as a consequence, this was often hindering to us, since they simply blocked a product line which we are also active in, with patent applications first, and then to an increasing degree with a multitude of patents." (R\&D Manager)

In the end, KBA did not actually pursue a blocking strategy, at least not with respect to the important new printing cylinder width (see below). Rather, they used the threat of blocking for licensing.

Generating licensing revenue apparently became an important goal for KBA. As we explain in the Discussion section, they no longer considered patents as a purely defensive means to maintain a balance with its competitors, but adopted a gain frame toward IP rights:

(h) "Today, we talk about licensing. I actually perceive this as a new business area at Koenig \& Bauer: to open up new sources of revenue from IP rights. The ROI is probably not that bad." (R\&D Manager)

Another interviewee specified that the introduction of the new cylinder width was a trigger for KBA's increased emphasis on licensing income:

20 While both KBA and Manroland touted their high patenting rates as signals of technology leadership and innovativeness in annual reports and press releases (e.g. http://www.kba-print.de/de/investor/berichte/ 06.html, http://www.manroland.com/com/en/press_releases_company 3163.htm, both accessed 08/16/2012), our interviews clearly show that this usage of patents is not a major reason behind the increase. Also, the importance of the signaling function did not change significantly. 
(i) "In particular there was one case where we paid royalties. It dates from the time when

Koenig \& Bauer had dashed ahead and had built a very dense network of IP rights. This technology 6-2 [...]" (IP Manager)

Cross-licensing accordingly became more important. In fact, this development had already started before KBA sought royalties from Manroland, and it appears that the increase in the importance of cross-licensing was another trigger for KBA to initiate the patent portfolio race. While we observe very few patent infringement conflicts on the court level ${ }^{21}$, qualitative evidence from interviews suggests that cross-licensing in the industry has grown over the last years, and that behind-the-scenes enforcement is intensive. In such a situation, patents fulfill an important function as bargaining chips, which creates an incentive to grow patent portfolios in order to improve one's bargaining position. Using an analogy from soccer, where a yellow card constitutes a reprimand by the referee, one interviewee stated:

(j) "Almost every day we show each other the yellow card. Manroland, KBA, WIFAG-dayto-day it is the same discussion." (IP Manager)

\section{Changes in the effectiveness of patents}

By the end of the 20th century, newspaper printing technology had reached a level of sophistication at which patents played a less important role than product complexity for the protection of a whole printing machine against imitation through competitors or new entrants. It was deemed unlikely that competitors, having their own established product lines, would imitate an entire printing machine. However, there was a perceived risk that competitors might imitate new product features or subsystems, and patents were used to prevent such kind of imitation. According to our interviews the belief evolved at KBA towards the end of the 1990s that individual patents were no longer sufficiently effective for this purpose, the main reason being that inventing around a single patent is rather simple for a competitor with comparable know-how. As a consequence, KBA started to build up patent fences (cf. Granstrand, 1999). Using an analogy from navigation, one interviewee commented on how numerous narrower patents are more effective than fewer broad patents:

21 We used the LexisNexis database for a systematic search of reports on such conflicts. Further, we inquired about such conflicts at German district courts. Finally, all interviewees were asked whether they knew about court-level conflicts. 
(k) 'Me, too, I'd rather have ten small barriers in the water than a single big one; because the latter is easy to circumnavigate." (IP Manager)

The impact of low perceived patent effectiveness on patenting strategy that we observe here is in line with findings by Cohen et al. (2000, p. 25), who state that "[f]irms do not, however, build such patent fences because individual patents effectively prevent imitation or substitution, but because they do not."

\section{Changes in the cost of patents}

In the 1990s, an important change in the non-monetary costs of procuring patents occurred, when technological developments created additional opportunities for patenting. At the Drupa trade fair in 2000, KBA introduced new product variations such as the Commander 6/2®, Commander CT®, and automation modules such as RollerTronic $®$, NipTronic $®$, and PlateTronic $®$. In particular the Commander $6 / 2 \AA$, a printing machine based on a new larger printing cylinder format, is relevant in our context. While these innovations were not major enough to explain the quadrupling in the number of KBA's patent applications, the introduction of broader printing cylinders offered numerous opportunities for filing patents (as we explain in detail below), thus effectively reducing the cost of patents.

\section{Changes in patent filing strategies}

A combination of the above effects - changes in the perceived benefits, effectiveness, and costs of patents - led KBA to change its patent filing strategy in such a way that its patent output was greatly increased. An important aspect of this change is the dual approach of "more patented inventions" and "more patents per invention", as we explain in the Discussion section. We propose that this causal linkage can be generalized to other, similar situations and put down our second proposition.

Proposition 2. In an industry with concentrated patent ownership and stable patenting rates, significant changes in the perceived benefits, efficiency, or costs of patents can trigger a firm to change its patent filing strategy, leading to an increase in its patenting output.

A change in the perceived benefits of patents led KBA also to adopt a different stance toward patenting - a gain frame - as illustrated in particular by Quote (h) from the perspective 
of KBA's competitor. Again, we propose that this mechanism can be generalized beyond our case study.

Proposition 3. Changes in the perceived benefits of patents may lead to changes in a firm's patent filing strategy through the adoption of a gain frame toward increases in patenting.

\section{Effectuating increases in patenting}

Having shown why KBA changed its patent filing strategy toward an increased patenting output, we now look at how the firm, and Manroland in response, effectuated this increase. We identified four measures: patenting different layouts of the same invention; filing narrower patents; patenting combinations of inventions; and patenting minor inventions. We address each in turn.

Patenting different layouts of the same invention is an obvious approach to building patent fences. In doing so, the patentee protects its inventions not only against direct imitation, but also against substitution and invent-around.

Filing narrower patents means that an invention is protected by multiple narrower patents instead of one broad patent, which can conveniently be achieved through divisional applications. European patent law allows applicants to split up a patent application into two or more applications as long as subject matter is not extended (Article 76 European Patent Convention). Similar procedures are available at the GPTO (\$39 PatG, German Patent Code) and the United States Patent and Trademark Office. We find that divisional applications were often used to establish dense networks of narrower patents covering various features of the initial, sometimes very voluminous, application. For example, the application EP1233864 led to ten divisional applications. A closer analysis reveals that out of KBA's European patent applications in 2002, 32 percent resulted from splitting up other patent applications, as opposed to 6 percent in 1992. For comparison, divisional applications currently make up around 5 percent of all European patent applications (EPO, 2009, p. 5).

Filing patents on combinations of inventions means that, given two inventions, one patent would be filed for each invention separately, and a third one for a combination thereof. In some cases, it seems that even patents on new inventions in combination with state-of-the-art technology were filed. The introduction of a new printing cylinder width, mentioned above, offered ample opportunities for this approach and proved critical in inducing the arms race between KBA and Manroland. While the new format did not change the technical mode of 
operation of printing machines in principle, existing components such as drive systems underwent adaptations. While many engineers believed that neither the broader printing cylinder nor the modified components were inventive enough to be patentable (see quotes $(l)$ and $(m)$ below), KBA succeeded in securing patents on combinations. Pursuing this approach, they were even able to build a thicket of patent rights covering the new cylinder format. To underscore, KBA did not pioneer the use of the wider printing cylinders; several firms had begun to use the new technology, but no one had secured intellectual property on that technology so far.

In addition, we find examples where new inventions were not only combined with other technology, but with known machine parameters such as temperature. In a patent application on a new mode of utilization of printing ink (EP1446290) the minimum temperature of $30^{\circ} \mathrm{C}$ of the plate cylinder of a printing machine was added to the claims. Interviewed engineers told us that $30^{\circ} \mathrm{C}$ is somewhat the standard operating temperature of such cylinders. However, this is common knowledge rather than documented information, and was thus not identified by the patent examiner as belonging to the state of the art. Interestingly, the above-mentioned patent has three European divisional applications.

Filing patents on minor inventions: Patents were also filed on inventions that would not have been deemed worth patenting some years ago. Thus, part of the increase in patenting is attributable to minor inventions. Commenting on why his firm did not increase patenting earlier, an interviewee stated:

(l) "It was somewhat depending on the self-conception of the engineers who did not file [patent applications for] each bagatelle that you have developed, reconfigured or implemented." ( $R \& D$ Manager)

Another interviewee criticized the competitor for filing rather trivial patents:

(m) "Today, if they draw a line on a paper, they would patent it." (Sales Manager)

Summarizing, the firms in the race used a dual approach of "more patented inventions" and "more patents per invention" to effectuate the increase in patenting. As illustrated by Quote $(l)$, this approach was facilitated by a change in the self-perception of engineers. While it used to be beneath their dignity to patent trivial inventions, they then adopted a more pragmatic stance toward increasing their respective employer's patent output. We capture this finding in the following proposition: 
Proposition 4. A change in the self-perception of engineers, entailing a pragmatic stance toward filing even trivial patents, facilitates a significant increase in patent output without a commensurate increase in innovation.

\section{Discussion}

\section{Initiating offensive patent portfolio races}

We observed and analyzed a patent arms race in the newspaper printing machines industry, an industry where patent ownership is concentrated to a few firms. In this setting, established explanations for patent portfolio races do not apply. We could also rule out any possible alternative explanations of increases in patenting output (i.e., increased inputs to R\&D, growth with the average, major M\&As, and the goal of erecting market entry barriers).

Our study contributes to the theory on motives to patent by distinguishing between defensive patent portfolio races, as demonstrated e.g. in the semiconductor industry and driven by fragmentation of patent ownership, and offensive patent portfolio races. The latter take place in an oligopoly with concentrated patent ownership; they are initiated by a specific industry participant that targets one or few competitors; and are of an offensive nature. While participants in a defensive portfolio race are unable to arrange ex-ante licensing due to transaction cost, those in an offensive race - at least the initiator - are unwilling to do so. A firm becomes unwilling to find ex-ante solutions when it adopts a gain frame towards increased patenting.

The model in Fig. 4 illustrates the mechanism behind offensive patent portfolio races. The race is triggered by changes in the first mover's perceived benefits, effectiveness, and/or costs of patents. These changes lead to a change in the firm's patent filing strategy, both through direct effects and indirectly, mediated through the adoption of a gain frame towards patenting. The change in patent filing strategy then entails an increase in patenting, facilitated by a change in the self-perception of the engineers devising the patentable inventions.

Changes in the environment may be sudden or continuous. But even if they are continuous, firm strategies are not continuously updated and so exhibit inertia. As a result, tension between the demands of the environment and the firm's strategy will build up until, at some point, they cause a sudden action in the form of a significant shift in strategy - much like tension in the earth's crust builds up to cause an earthquake. 
The first mover's shift from loss avoidance to a gain frame towards increased patenting initiated the breakdown of cooperation between firms - "cooperation" in the game-theoretic sense of keeping patenting rates at moderate, stable levels. By deviating from this equilibrium, the first mover caused its main competitor to react in kind, motivated by the perceived threat of holdup. Thus, the follower's motivation - to forestall holdup - is similar to that of players in a defensive patent portfolio race. The first mover's initial actions had a different origin though - an offensive origin. To the first mover the arrival of a new technology broader printing cylinders - reduced the cost of patenting, made the goal of generating licensing income more important, and made the firm adopt a gain frame towards increased patenting, i.e., a bias towards interpreting change as an opportunity to improve the competitive situation.

As the first mover adopts a gain frame towards increased patenting, the cooperative behavior that keeps patenting at low levels breaks down. Consider that patenting in oligopoly, just as pricing, constitutes a dimension of competition. Hence, in a similar way as prices may be supra-competitive, patenting rates in an industry may be below the competitive level. That is, each player would have an incentive to defect to higher patenting rates, but the threat of retaliation by its competitors would normally keep the cooperative situation stable. Such a situation is formally described in game theory by the folk theorems (e.g. Tirole, 1988) and akin to a cartel. A cartel may break down for a number of reasons (e.g., Hay and Kelley, 1974; Dick, 1996; Suslow, 2005; Levenstein and Suslow, 2006). Here, cooperation broke down as one firm perceived increased advantages of defecting from stable patenting rates.

\section{Long-term outcomes of offensive races}

Possible long-term outcomes of a patent arms race are a cooperative contractual solution, an outright patent war including high levels of litigation, and a leveling-off at higher patenting rates. As to contractual solutions to resolve mutual blocking with patents, patent pools and cross-licenses are common in the semiconductor and electronics industry (Shapiro, 2001). In a highly concentrated industry, however, patent pools would likely create antitrust issues. A limited cross-license would avoid antitrust problems, but would have to be renegotiated after a certain period and would, thus, not solve the problem. Since balancing payments are typically negotiated on the basis of patent counts, they create incentives for further patenting.

An outright patent war would be the most aggressive outcome, with juridical assertion of numerous patents and steadily growing patent portfolios. Such a situation is not observed in our study. This is in line with the folk theorem, according to which an equilibrium outcome is 
more stable the lower the temporary advantages from unilateral deviation (e.g. Tirole, 1988, p. 248). Since the benefit-cost ratio of a unilateral increase in patenting will become more unfavorable the higher the current patenting rates, one would expect a "truce" at some elevated level of patenting.

Such leveling-off at higher patenting rates is indeed what we observe. Manroland's managers were aware of the prisoner's dilemma-like situation, and felt forced into the arms race. They would likely not increase patenting further than necessary, i.e. until being on an eye level with KBA. Manroland's patenting at the GPTO indeed remained stable between 2004 and 2006, equal to KBA's prior level between 2000 and 2005. KBA, in turn, has not increased patenting since 2002 (but seems to have shifted some of its patenting activity from the EPO to the GPTO in 2006). Thus, it seems that some kind of informal coordination evolved that helped avoid a further escalation. Even explicit coordination would theoretically have been possible (though we have no indication that it took place), since we learned that IP and R\&D executives of all involved firms knew each other well and met regularly.

Once both parties' patenting had levelled off, none of them had any competitive advantage of the other (see Quotes $(b),(c)$ ). Also, as supported by Quotes $(e)$ and $(f)$, the elevated patenting rates did not provide them notable advantages vis-à-vis third parties. They did, however, entail increased costs and operative restrictions. We thus arrive at a normative proposition.

Proposition 5. In an industry with concentrated patent ownership and stable patenting rates, a unilateral significant increase in patent output will yield only temporary advantages for the first mover due to reactions by competitors. In the long term, the race worsens the participants' situation. Firms should thus consider long-term consequences before triggering a patent portfolio race.

\section{Welfare implications}

The welfare implications of a patent arms race are unfavorable. While the increase in patenting may have yielded temporary advantages for the first mover, in the long run a patent arms race reduces efficiency for all parties involved. In this vein, Cohen et al. (2000, p. 28) critically note that " [...] patent portfolio races [...] reflect excessive patenting from a social welfare perspective (as would typify a Prisoners' Dilemma-like situation), and are thus raising the cost of innovation unduly”. Guellec and van Pottelsberghe (2007, p. 81) characterize excessive use of patents as a zero- or negative-sum game and Jaffe (2000) argues that in the 
end, none of the firms increases its returns to innovation. In fact, innovation might even be hampered if engineers dedicate time to reading, writing, and enforcing patents at the expense of inventing and constructing new products.

Structurally, a patent arms race is similar to a price war. According to the folk theorem, in an oligopoly any pricing level within a certain range is sustainable as the equilibrium of a repeated pricing game. Unilateral deviation from this equilibrium yields short-term advantages for the deviating firm, but would trigger retaliation that could bring down the entire industry to a new equilibrium with reduced prices and profits. A patent arms race is even more precarious than a price war, for two reasons. First, the 18-month publication lag restricts observability of competitors' actions, which makes a unilateral breach of an implicit collusion (i.e. low levels of patenting) more attractive (e.g. Tirole, 1988, p. 248). Second, while price wars may be welfare enhancing overall since they benefit buyers, excessive patenting constitutes wasteful expenditures from a societal point of view.

\section{Limitations and future research}

Our study has a number of limitations and suggests avenues for future research. Since we focus on the machinery industry and identify differences to the semiconductor, electronics, and software industry, further studies on other industries such as pharmaceuticals or biotechnology are needed to draw a complete picture of causes and effects of patent portfolio races. Still, we would think that the portfolio race we analyze provides generalizable insights because the main ingredients are rather common and frequent: a tight oligopoly in a complex technology industry; low fragmentation of patent ownership; and limited effectiveness of individual patents.

Regarding the fact that the arms race took place between two German firms, we are confident that it does not restrict generalizability of our case study results (Eisenhardt and Graebner, 2007). It seems unlikely that the German legal system is an important driver of the arms race or of concentration of the relevant patent landscape. Market concentration is driven by cost and demand, which are to a high degree independent of the German legal system. In fact, all four firms sell internationally, e.g. KBA in 1999 more than 70\%; also prices for inputs such as steel are international. In turn, market concentration is - together with technology characteristics that make high vertical integration profitable - the most important driver of concentration of patent ownership. Further, the German patent system traditionally has higher standards of patentability than other patent systems, which should rather slow down arms rac- 
es than fueling them. In addition, while the pattern is clearer at the GPTO we observe the arms race also at the EPO.

We could clearly show that the observed increases in patenting were not mainly driven by heightened inventive activity and that patenting rates are, within boundaries, somewhat arbitrary. However, we did not precisely identify what share of patent applications was attributable to the strategy of harvesting more patents from a given number of inventions. Thus, an avenue for future research would be to measure the extent of such strategies more precisely. Our analysis of divisional applications, combinatorial patents, and multiple filings may constitute a starting point to such analysis. Recent changes in European patent legislation to limit the abuse of divisional patent applications underline the need for action in this field. ${ }^{22}$ Further studies should be undertaken to supply policy makers with the relevant information.

\section{Implications for managers and policy makers}

Our study provides a number of insights for managers, showing what may cause a patenting increase by a competitor and what effects an increase of own patenting may have on others. We suggest that patent portfolio races, while yielding temporary advantages for the first mover, are likely suboptimal in the long run. Indeed, to be effective the gain from triggering a race must offset the cost from retaliation. Except for transient royalty income, the effects on profits will likely be negative due to increased costs of filing, monitoring, defending, and challenging patents. Innovation may actually suffer because engineers have to dedicate more time to patent management. Managers should, thus, think twice before initiating a patent portfolio race.

On the policy level, our findings suggest that the patent system was fueling the arms race. The ability to obtain patents on minor inventions, combinations of state-of-the-art or machine parameters with new inventions, and the availability of divisional applications were central elements in the strong increase in patenting that we observed. These possibilities led many of our interviewees to perceive the patent offices" grant policy as "lax", in particular at the EPO (compared to the GPTO). Not surprisingly, firms' perception of being able to obtain patents quite easily constitutes an additional incentive to file more patents. This finding implies, once

22 Decision of the Administrative Council of 25 March 2009 amending the Implementing Regulations to the European Patent Convention (CA/D 2/09): http://archive.epo.org/epo/pubs/oj009/05 09/05_2969.pdf (accessed 13 March 2014). 
more, that patent offices should consider raising the patentability threshold. Furthermore, it supports existing criticism that rising patent application numbers should not be celebrated as signs of increasing innovativeness, but rather should be closely scrutinized as indications of problems in the patent system. 


\section{References}

Ahuja, G., Coff, R.W., Lee, P.M., 2005. Managerial foresight and attempted rent appropriation: Insider trading on knowledge of imminent breakthroughs. Strategic Management Journal 26 (9), 791-808.

Arora, A., Fosfuri, A., Gambardella, A., 2001. Markets for Technology. MIT Press: Cambridge, MA.

Arundel, A., 2001. The relative effectiveness of patents and secrecy for appropriation. Research Policy 30 (4), 611-624.

Arundel, A., Patel, P., 2003. Strategic patenting. Background report for the Trend Chart Policy Benchmarking Workshop "New Trends in IPR Policy": Luxembourg. MA.

Bain, J.S., 1956. Barriers to New Competition. Harvard University Press: Cambridge,

Bessen, J., Meurer, M.J., 2008. Patent failure: How judges, bureaucrats, and lawyers put innovators at risk. Princeton University Press: Princeton.

Blind, K., Cremers, K., Mueller, E., 2009. The influence of strategic patenting on companies patent portfolios. Research Policy 38 (2), 428-436.

Blind, K., Edler, J., Frietsch, R., Schmoch, U., 2006. Motives to patent: Empirical evidence from Germany. Research Policy 35 (5), 655-672.

Caves, R.E., 1974. Industrial organization. In: Dunning, J.H. (Ed.), Economic Analysis and the Multinational Enterprise. Praeger, New York, pp. 115-146.

Caves, R.E., Whinston, M.D., Hurwitz, M.A., 1991. Patent expiration, entry, and competition in the U.S. pharmaceutical industry. Brookings Papers on Economic Activity: Microeconomics, 1-66.

Cockburn, I.M., MacGarvie, M., 2009. Patents, thickets, and the financing of early-stage firms: Evidence from the software industry. Journal of Economics \& Management Strategy 18 (3), 729-773.

Cohen, W.M., Nelson R.R., Walsh, J.P., 2000. Protecting their intellectual assets: Appropriability conditions and why U.S. manufacturing firms patent (or not), NBER Working Paper, No. 7552. National Bureau of Economic Research, Cambridge, MA.

Dasgupta, P., Stiglitz, J., 1980. Uncertainty, industrial structure, and the speed of R\&D. Bell Journal of Economics 11 (1), 1-28.

Dick, A.R., 1996. When are cartels stable contracts? Journal of Law and Economics 39(1): 241-83.

Eisenhardt, K.M., 1989. Building theories from case study research. Academy of Management Review 14 (4), 532-550. 
Eisenhardt, K.M., Graebner , M.E., 2007. Theory building from cases: Opportunities and challenges. Academy of Management Journal 50 (1), 25-32.

Gilroy, L., Amato, T. D., 2009. How many patents does it take to build an iPhone. Intellectual Property Today, (November 2009).

Granstrand, O., 1999. The Economics and Management of Intellectual Property. Edward Elgar: London.

Grindley, P.C., Teece, D.J., 1997. Managing intellectual capital: Licensing and crosslicensing in semiconductors and electronics. California Management Review 39 (2), 8-41.

Guellec, D. and van Pottelsberghe, B., 2007. The Economics of the European Patent System: IP Policy for Innovation and Competition. Oxford University Press: Oxford, UK.

Hall, B.H., 2005. Exploring the patent explosion. Journal of Technology Transfer 30 (12), 35-48.

Hall, B.H., Ziedonis, R.H., 2001. The patent paradox revisited: An empirical study of patenting in the U.S. semiconductor industry, 1979-1995. RAND Journal of Economics 32 (1), $101-128$.

Harhoff, D., Hall B., 2002. Intellectual property strategy in the global cosmetics industry. Working Paper, Ludwig-Maxmilians-Universität München and University of California Berkeley.

Harhoff, D., Reitzig, M., 2004. Determinants of opposition against EPO patent grants: The case of biotechnology and pharmaceuticals. International Journal of Industrial Organizations 22 (4), 443-480.

Harhoff, D., Scherer, F.M., Vopel, K., 2003. Citations, family size, opposition and the value of patent rights. Research Policy 32 (8), 1343-1363.

Hay, G.A., Kelley, D., 1974. An empirical survey of price fixing conspiracies. Journal of Law and Economics 17(1): 13-38.

Heller, M.A., 2008. The Gridlock Economy: How Too Much Ownership Wrecks Markets, Stops Innovation, and Costs Lives. Basic Books: New York.

Heller, M.A., Eisenberg, R.S., 1998. Can patents deter innovation? The anticommons in biomedical research. Science 280 (5364), 698-701.

Hoenen, S., Kolympiris, C., Schoenmakers, W., Kalaitzandonakes, N., 2014. The diminishing signaling value of patents between early rounds of venture capital financing. Research Policy, forthcoming.

Hsu, D., Ziedonis, R., 2013. Resources as dual sources of advantage: Implications for valuing entrepreneurial-firm patents. Strategic Management Journal 34, 761-781. 
Jaffe, A.B., 2000. The U.S. patent system in transition: Policy innovation and the innovation process. Research Policy 29 (4-5), 531-557.

Jell, F., Henkel, J., Hoisl, K., 2013. The relationship between patenting motives and pendency durations. Working Paper, Technische Universität München. http://ssrn.com/abstract=2406536.

Jenkins, M., 2014. Innovate or imitate? The role of collective beliefs in competences in competing firms. Long Range Planning 47, 173-185.

Kash, D.E., Kingston, W., 2001. Patents in a world of complex technologies. Science and Public Policy 28 (1), 11-22.

Kim, J., Marschke, G., 2004. Accounting for the recent surge in U.S. patenting: changes in R\&D expenditures, patent yields, and the high tech sector. Economics of Innovation and New Technology 13 (6), 543-558.

Kortum, S., Lerner, J., 1999. What is behind the recent surge in patenting. Research Policy $28,1-22$.

Lanjouw, J.O., Lerner, J., 2001. Tilting the table? The use of preliminary injunctions. Journal of Law and Economics 44 (2), 573-603.

Lemley, M.A., Shapiro, C., 2007. Patent holdup and royalty stacking. Texas Law Review 85, 1991-2048.

Levenstein, M.C., Suslow, V.Y., 2006. What determines cartel success? Journal of Economic Literature 44, 43-95.

Levin, R.C., Klevorick, A.K., Nelson, R.R., Winter, S.G., 1987. Appropriating the returns from industrial research and development. Brookings Papers on Economic Activity 3, 783-831.

Loury, G.C., 1979. Market structure and innovation. Quarterly Journal of Economics 93 (3), 395-410.

Macdonald, S., 2001. Managing with method: Information for innovation. In: Lamberton, D. (Ed.), Managing the Global: Globalisation, Employment and Quality of Life. Tauris, London, UK, pp. 209-221.

Macdonald, S., 2004. When means become ends: Considering the impact of patent strategy on innovation. Information Economics and Policy 16 (1), 135-158.

Macher, J., Mowery, D.C., Hodges, D., 1999. Semiconductors. In: Mowery, D.C. (Ed.),U.S. Industry in 2000: Studies in Competitive Performance. National Acad. Press, Washington, D.C., pp. 245-285.

Mansfield, E., 1986. Patents and innovation: An empirical study. Management Science 32 (2), 173-181. 
Mayring, P., 2004. Qualitative content analysis. In: Flick, U., von Kardoff E., Steinke, I. (Eds.), A Companion to Qualitative Research. Sage, London, UK., pp. 266-269.

Merges, R.P., 1999. As many as six impossible patents before breakfast: Property rights for business concepts and patent system reform. Berkeley Technology Law Journal 14 (2), 577-616.

Messeni Petruzzelli, A. Savino, T., 2014. Search, recombination, and innovation: Lessons from haute cuisine. Long Range Planning 47, 224-238.

Noel, M., Schankerman, M., 2006. Strategic patenting and software innovation. Research Paper No. EI43, The Toyota Centre Suntory and Toyota International Centres for Economics and Related Disciplines and London School of Economics and Political Science.

OECD Patent Statistics Manual, 2009. OECD, http://www.oecd.org/innovation/ innovationinsciencetechnologyandindustry/oecdpatentstatisticsmanual.htm. Accessed 03/14/2014.

Porter, M.E., 1980. Competitive Strategy. Free Press: New York.

Rabino, S., Enayati, E., 1995. Intellectual property: The double-edged sword. Long Range Planning 28(5), 22-31.

Ramani, G., Kumar, V., 2008. Interaction orientation and firm performance. Journal of Marketing

72(1), 27-45.

Reinganum, J., 1982. A dynamic game of R and D: Patent protection and competitive behavior. Econometrica 50 (3), 671-688.

Reitzig, M., 2004a. Strategic management of intellectual property. MIT Sloan Management Review 45 (3), 35-40.

Reitzig, M., 2004b. The private values of thickets and fences: towards an updated picture of the use of patents across industries. Economics of Innovation and New Technology 13 (5), $457-477$.

Reitzig, M., 2007. How executives can enhance IP strategy and performance. MIT Sloan Management Review 49 (1), 37-43

Reitzig, M., Henkel, J., Heath, C.H., 2007. On sharks, trolls, and their patent prey - Unrealistic damage awards and firms strategies of being infringed. Research Policy 36 (1), 134 154.

Rivette, K.G., Kline, D., 2000a. Discovering new value in intellectual property. Harvard Business Review 78 (1), 54-66.

Rivette, K.G., Kline, D., 2000b. Rembrandts in the Attic: Unlocking the Hidden Value of Patents. Harvard Business School Press, Boston, MA.

Sattler, H., 2003. Appropriability of product innovations: An empirical analysis for 
Germany. International Journal of Technology Management 26 (5/6), 502-516.

Scherer, F.M., 1983. The propensity to patent. International Journal of Industrial Organization 1(1), 107-128.

Schmoch, U., F. Laville, P. Patel, R. Frietsch (2003), Linking Technology Areas to Industrial Sectors, final report to the European Commission, DG Research.

Scotchmer, S., 1991. Standing on the shoulders of giants: Cumulative research and the patent law. Journal of Economic Perspectives 5 (1), 29-41.

Shah, S.K., Corley, K.G., 2006. Building better theories to bridge the qualitativequantitative divide. Journal of Management Studies 43 (8), 1821-1835.

Shapiro, C., 2001. Navigating the patent thicket: Cross-licenses, patent pools, and standard-setting. In: Jaffe, A., Lerner, J., Stern, S. (Eds.), Innovation Policy and the Economy. MIT Press, Cambridge, MA, pp. 119-150.

Steidle, P., 2003. Presentation by Paul Steidle, member of the executive board of Manroland AG, "Situation und Trends im Rollenakzidenzdruck", Jahrestagung des VDD, 10/24/03, Düsseldorf. http://www.vdd-net.de/images/pdf/Veranstaltungen/Tagungen/ MV2003/VDD2003-Steidle.pdf. Accessed 03/14/2014.

Suslow, Valerie Y., 2005. Cartel contract duration: Empirical evidence from inter-war international cartels. Industrial and Corporate Change 14 (5), 705-44.

Tirole, J., 1988. The Theory of Industrial Organization. MIT Press: Cambridge, MA.

von Hippel, E., 1988. The Sources of Innovation. Oxford University Press: New York.

Wagner, S., 2008. Business method patents in Europe and their strategic use: Evidence from fran-king device manufacturers. Economics of Innovation and New Technology 17 (3), 173-194.

Williamson, O.E., 1985. The Economic Institutions of Capitalism. Free Press: New York.

Yin, R.K., 2003. Case study research: Design and methods. Sage: Newbury Park, CA.

Ziedonis, R.H., 2003. Patent litigation in the semiconductor industry. In: Cohen, W., Merrill, S. (Eds.), Patents in the Knowledge-Based Economy. National Acad. Press, Washington, DC, pp. 180-215.

Ziedonis, R.H., 2004. Don't fence me. In: Fragmented markets for technology and the patent acquisition strategies of firms. Management Science 50 (6), 804-820. 
Figures and Table

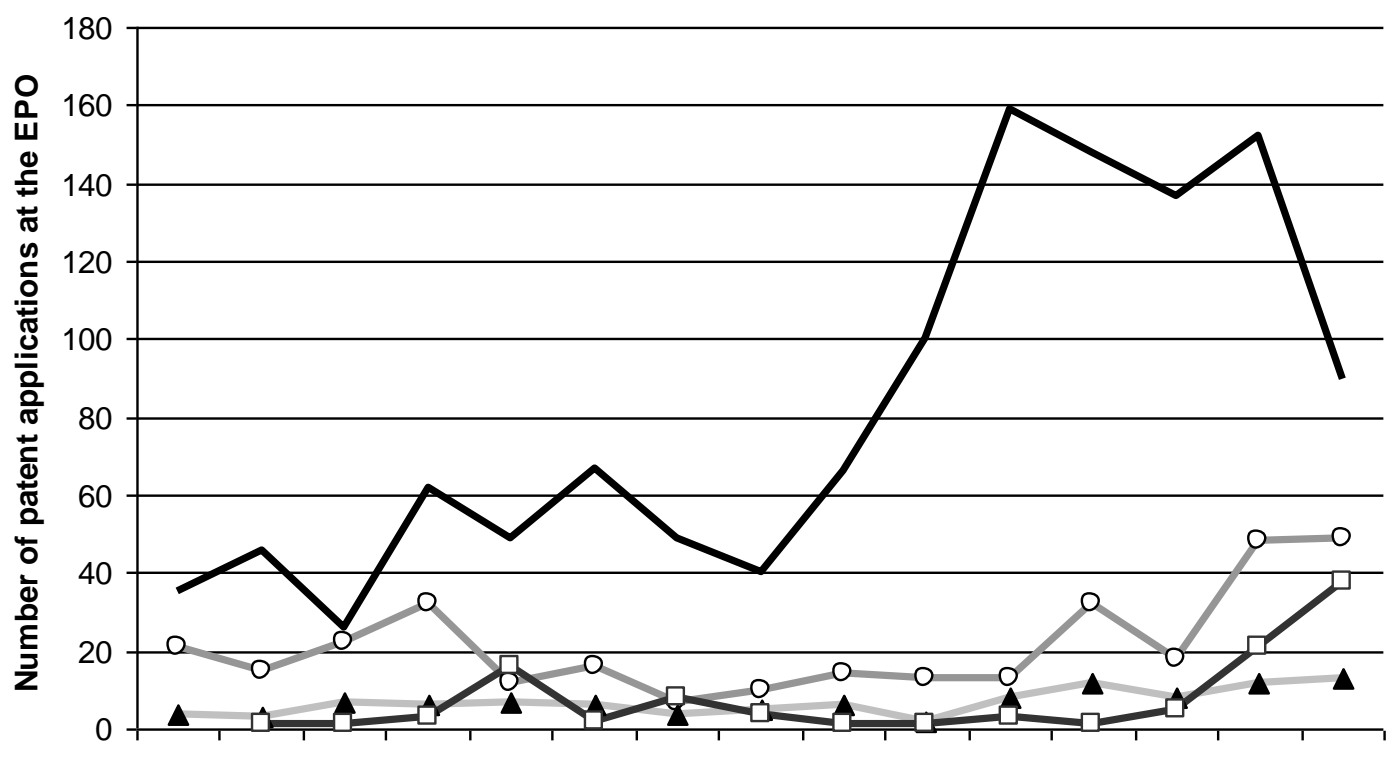

199219931994199519961997199819992000200120022003200420052006

Year of filing

KBA $\quad \mathrm{O}-$ Manroland

$\triangle$ WIFAG

$-\square-$ Goss

Fig. 1: Number of newspaper printing machines related patent applications at the EPO by manufacturer (1992 to 2006)

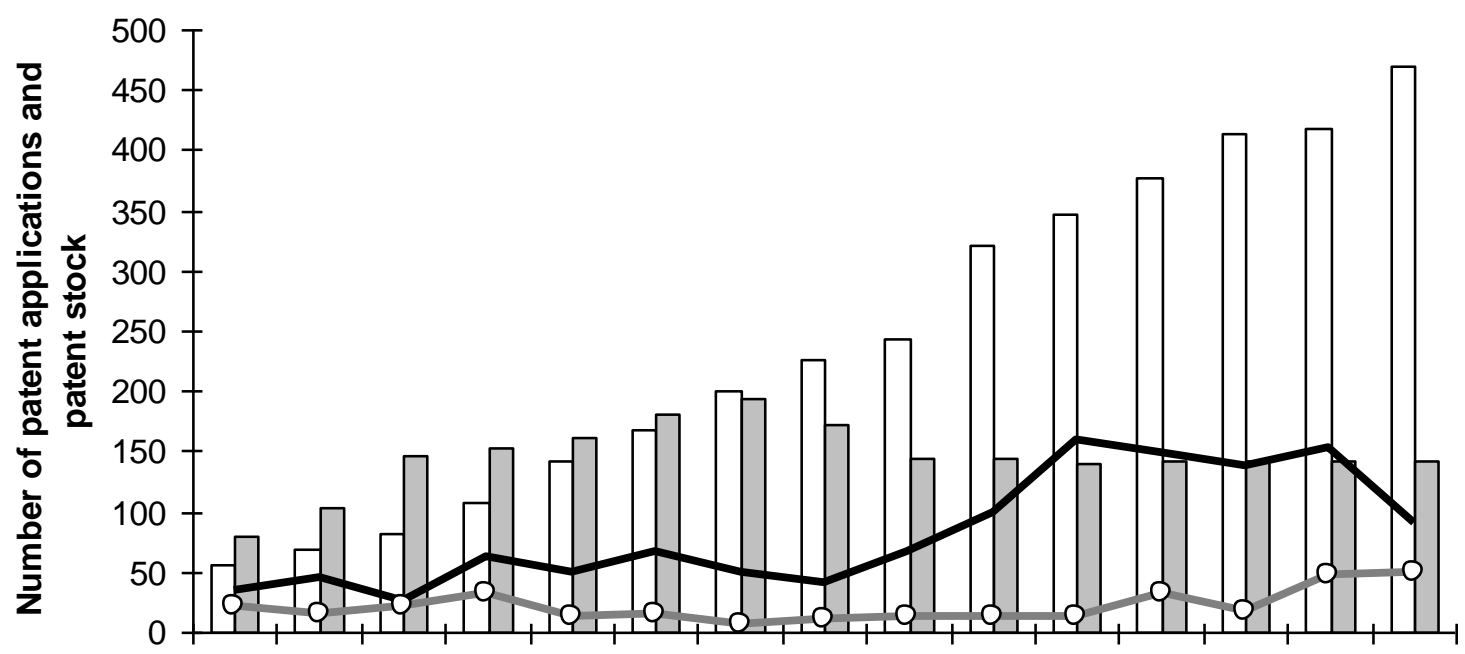

199219931994199519961997199819992000200120022003200420052006

\section{Year}

$\square$ KBA - stock of German patents granted by EPO

$\square$ Manroland - stock of German patents granted by EPO

- KBA - patent applications at EPO

-O- Manroland - patent applications at EPO

Fig. 2: Stock of active German newspaper printing patents (granted by the EPO) and patent applications (at the EPO) 


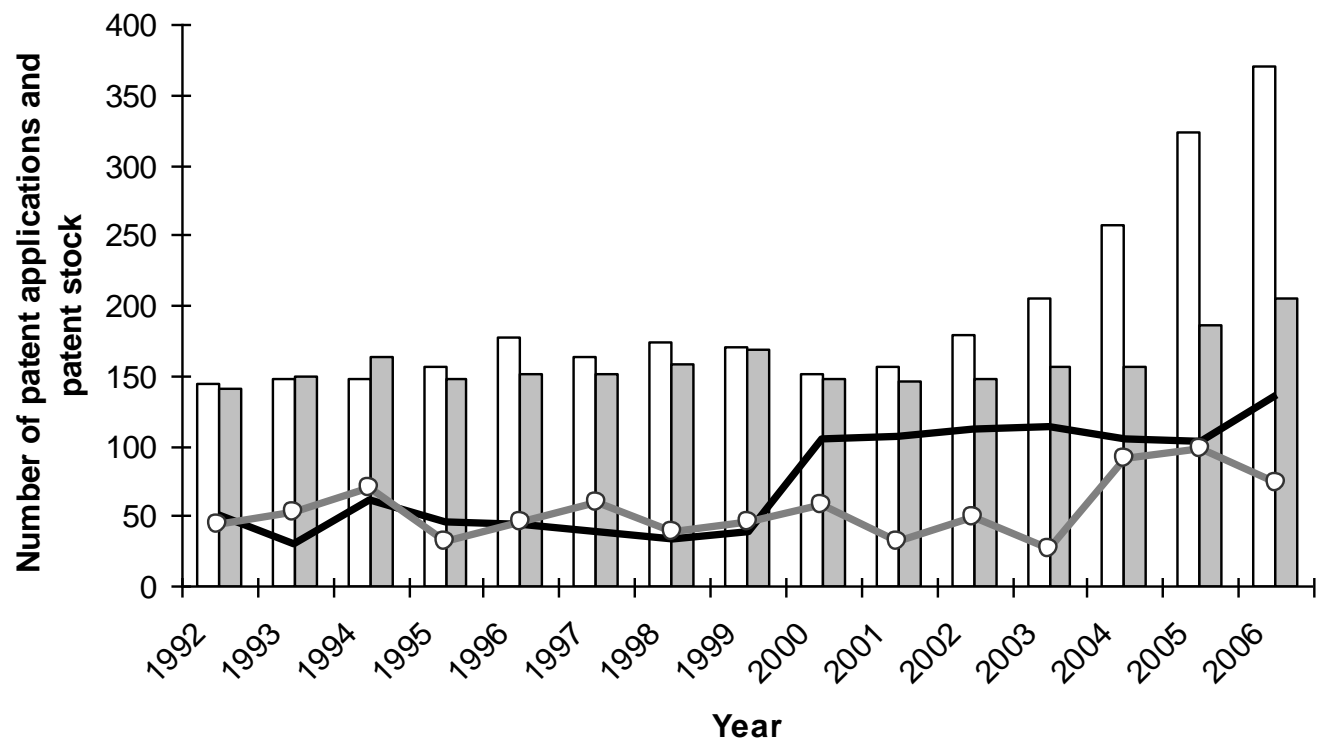

$\square$ KBA - stock of German patents granted by GPTO

$\square$ Manroland - stock of German patents granted by GPTO

KBA - patent applications at GPTO

- - Manroland - patent applications at GPTO

Fig. 3: Stock of active German newspaper printing patents (granted by the GPTO) and patent applications (at the GPTO)

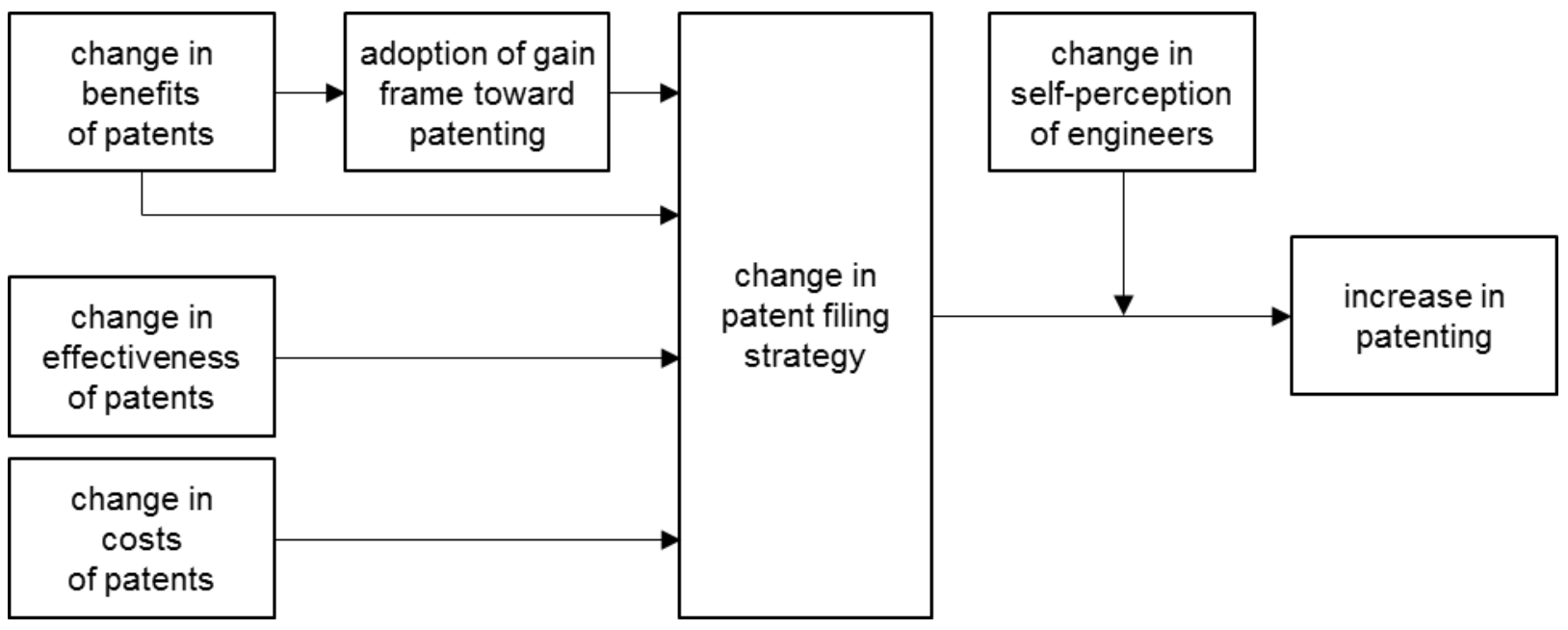

Fig. 4: Mechanism of offensive patent portfolio races

Table 1: R\&D headcount (source: annual reports of KBA and Manroland)

\begin{tabular}{lllllllllll}
\hline Year: & 1997 & 1998 & 1999 & 2000 & 2001 & 2002 & 2003 & 2004 & 2005 & 2006 \\
\hline KBA: & -- & 735 & 775 & 802 & 866 & 890 & -- & -- & -- & 800 \\
& & & & & & & & & & \\
\hline Manroland: & 1200 & 1050 & 804 & 1126 & 1183 & 1096 & 1022 & 901 & -- & -- \\
\hline
\end{tabular}




\section{Appendix}

Summary Table of all interviews (interviews with several iterations are marked bold)

\begin{tabular}{|c|c|c|c|c|c|c|}
\hline & Company & Company type & Interviewee role & Country & Year & Duration \\
\hline 1 & $\mathbf{K B A}$ & $\begin{array}{l}\text { Printing machines manufac- } \\
\text { turer (newspaper) }\end{array}$ & $\begin{array}{l}\text { Head of Intellectual } \\
\text { Property }\end{array}$ & $\mathrm{DE}$ & 2008 & $60 \mathrm{~min}$ \\
\hline 2 & $\mathbf{K B A}$ & $\begin{array}{l}\text { Printing machines manufac- } \\
\text { turer (newspaper) }\end{array}$ & Head of R\&D & $\mathrm{DE}$ & 2008 & $40 \mathrm{~min}$ \\
\hline 3 & $\mathrm{KBA}$ & $\begin{array}{l}\text { Printing machines manufac- } \\
\text { turer (newspaper) }\end{array}$ & General Manager & UK & 2008 & $30 \mathrm{~min}$ \\
\hline 4 & Manroland & $\begin{array}{l}\text { Printing machines manufac- } \\
\text { turer (newspaper) }\end{array}$ & $\begin{array}{l}\text { Head of Intellectual } \\
\text { Property }\end{array}$ & $\mathrm{DE}$ & 2008 & $60 \mathrm{~min}$ \\
\hline 5 & Manroland & $\begin{array}{l}\text { Printing machines manufac- } \\
\text { turer (newspaper) }\end{array}$ & Head of $R \& D$ & $\mathrm{DE}$ & 2007 & $60 \mathrm{~min}$ \\
\hline 6 & WIFAG & $\begin{array}{l}\text { Printing machines manufac- } \\
\text { turer (newspaper) }\end{array}$ & $\begin{array}{l}\text { Head of Intellectual } \\
\text { Property }\end{array}$ & $\mathrm{CH}$ & 2008 & $60 \mathrm{~min}$ \\
\hline 7 & WIFAG & $\begin{array}{l}\text { Printing machines manufac- } \\
\text { turer (newspaper) }\end{array}$ & Head of $R \& D$ & $\mathrm{CH}$ & 2008 & $50 \mathrm{~min}$ \\
\hline 8 & WIFAG & $\begin{array}{l}\text { Printing machines manufac- } \\
\text { turer (newspaper) }\end{array}$ & $\begin{array}{l}\text { Communications } \\
\text { Manager }\end{array}$ & $\mathrm{CH}$ & 2008 & $20 \mathrm{~min}$ \\
\hline 9 & GOSS & $\begin{array}{l}\text { Printing machines manufac- } \\
\text { turer (newspaper) }\end{array}$ & General Manager & US & 2008 & $30 \mathrm{~min}$ \\
\hline 10 & Heidelberger & $\begin{array}{l}\text { Printing machines manufac- } \\
\text { turer (other) }\end{array}$ & $\begin{array}{l}\text { Head of Intellectual } \\
\text { Property }\end{array}$ & $\mathrm{DE}$ & 2008 & $30 \mathrm{~min}$ \\
\hline 11 & Heidelberger & $\begin{array}{l}\text { Printing machines manufac- } \\
\text { turer (other) }\end{array}$ & R\&D Manager & $\mathrm{DE}$ & 2007 & $40 \mathrm{~min}$ \\
\hline 12 & Ryobi & $\begin{array}{l}\text { Printing machines manufac- } \\
\text { turer (other) }\end{array}$ & General Manager & $\mathrm{DE}$ & 2008 & $30 \mathrm{~min}$ \\
\hline 13 & Ryobi & $\begin{array}{l}\text { Printing machines manufac- } \\
\text { turer (other) }\end{array}$ & General Manager & $\mathrm{DE}$ & 2008 & $10 \mathrm{~min}$ \\
\hline 14 & $\begin{array}{l}\text { Mitsubishi } \\
\text { Heavy Ind. }\end{array}$ & $\begin{array}{l}\text { Printing machines manufac- } \\
\text { turer (other) }\end{array}$ & General Manager & $\mathrm{DE}$ & 2008 & $20 \min$ \\
\hline 15 & KOMORI & $\begin{array}{l}\text { Printing machines manufac- } \\
\text { turer (other) }\end{array}$ & General Manager & $\mathrm{DE}$ & 2008 & $20 \mathrm{~min}$ \\
\hline 16 & Müller Martini & $\begin{array}{l}\text { Printing machines manufac- } \\
\text { turer (other) }\end{array}$ & Managing Director & $\mathrm{DE}$ & 2008 & $30 \mathrm{~min}$ \\
\hline 17 & Presstek & $\begin{array}{l}\text { Printing machines manufac- } \\
\text { turer (other) }\end{array}$ & General Manager & $\mathrm{DE}$ & 2008 & $20 \mathrm{~min}$ \\
\hline 18 & Axel Springer & $\begin{array}{l}\text { Printing machines user } \\
\text { (newspaper printing plant) }\end{array}$ & $\begin{array}{l}\text { Chief technology } \\
\text { officer }\end{array}$ & $\mathrm{DE}$ & 2009 & $60 \mathrm{~min}$ \\
\hline 19 & $\begin{array}{l}\text { Stuttgarter } \\
\text { Zeitung }\end{array}$ & $\begin{array}{l}\text { Printing machines user } \\
\text { (newspaper printing plant) }\end{array}$ & $\begin{array}{l}\text { Chief technology } \\
\text { officer }\end{array}$ & $\mathrm{DE}$ & 2009 & $50 \mathrm{~min}$ \\
\hline 20 & $\begin{array}{l}\text { Axel Springer } \\
\text { Berlin }\end{array}$ & $\begin{array}{l}\text { Printing machines user } \\
\text { (newspaper printing plant) }\end{array}$ & $\begin{array}{l}\text { Chief technology } \\
\text { officer }\end{array}$ & $\mathrm{DE}$ & 2009 & $30 \mathrm{~min}$ \\
\hline 21 & $\begin{array}{l}\text { Axel Springer } \\
\text { Ahrensburg }\end{array}$ & $\begin{array}{l}\text { Printing machines user } \\
\text { (newspaper printing plant) }\end{array}$ & $\begin{array}{l}\text { Chief technology } \\
\text { officer }\end{array}$ & $\mathrm{DE}$ & 2009 & $35 \mathrm{~min}$ \\
\hline
\end{tabular}




\begin{tabular}{lllllll}
\cline { 2 - 6 } 22 & VDMA & Manufacturers association & $\begin{array}{l}\text { Industry expert } \\
\text { (general) }\end{array}$ & DE & 2008 & 15 min \\
\hline 23 & EPO & Patent office & $\begin{array}{l}\text { Examiner (printing } \\
\text { technology) }\end{array}$ & DE & 2007 & 50 min \\
\hline
\end{tabular}

The use of data sources

\begin{tabular}{|c|c|c|c|}
\hline & Data source & Type of data & Results reported \\
\hline 1 & Interviews & $\begin{array}{l}\text { Recorded audio files; tran- } \\
\text { scribed text }\end{array}$ & $\begin{array}{l}\text { Individual case descriptions } \\
\text { Industry descriptions } \\
\text { Quotes }\end{array}$ \\
\hline 2 & PATSTAT & $\begin{array}{l}\text { Number of applications, De- } \\
\text { gree of fragmentation }\end{array}$ & $\begin{array}{l}\text { Calculation of Ziedonis index } \\
\text { Timing of patent applications }\end{array}$ \\
\hline 3 & INPADOC & $\begin{array}{l}\text { Information on patent process } \\
\text { (grant \& expiry dates) }\end{array}$ & $\begin{array}{l}\text { Construction of patent portfolios } \\
\text { (granted \& effective patents) }\end{array}$ \\
\hline 4 & Compustat & Revenue, $\mathrm{P} \& \mathrm{~L}$ & Descriptive data \\
\hline 5 & Thomson/Reuters & Revenue, P\&L & Descriptive data \\
\hline 6 & LexisNexis & $\begin{array}{l}\text { Acquisitions } \\
\text { Important events (such as } \\
\text { court proceedings) }\end{array}$ & $\begin{array}{l}\text { Individual case descriptions } \\
\text { Industry descriptions }\end{array}$ \\
\hline 7 & Annual reports & $\begin{array}{l}\text { R\&D spending } \\
\text { Acquisitions } \\
\text { Dates of product lunches }\end{array}$ & $\begin{array}{l}\text { Individual case descriptions } \\
\text { Industry descriptions }\end{array}$ \\
\hline
\end{tabular}




\section{USPTO applications}

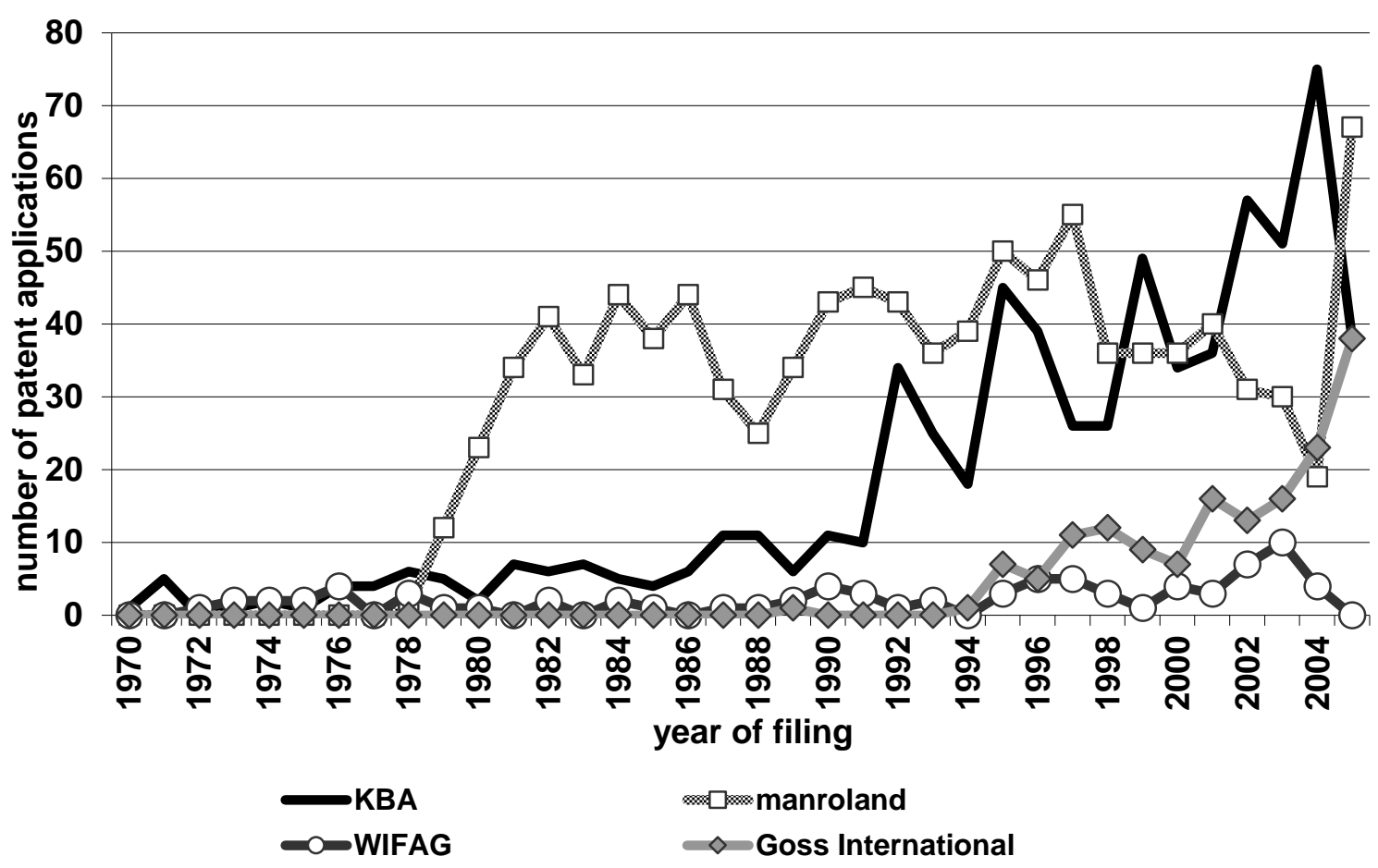

PCT applications

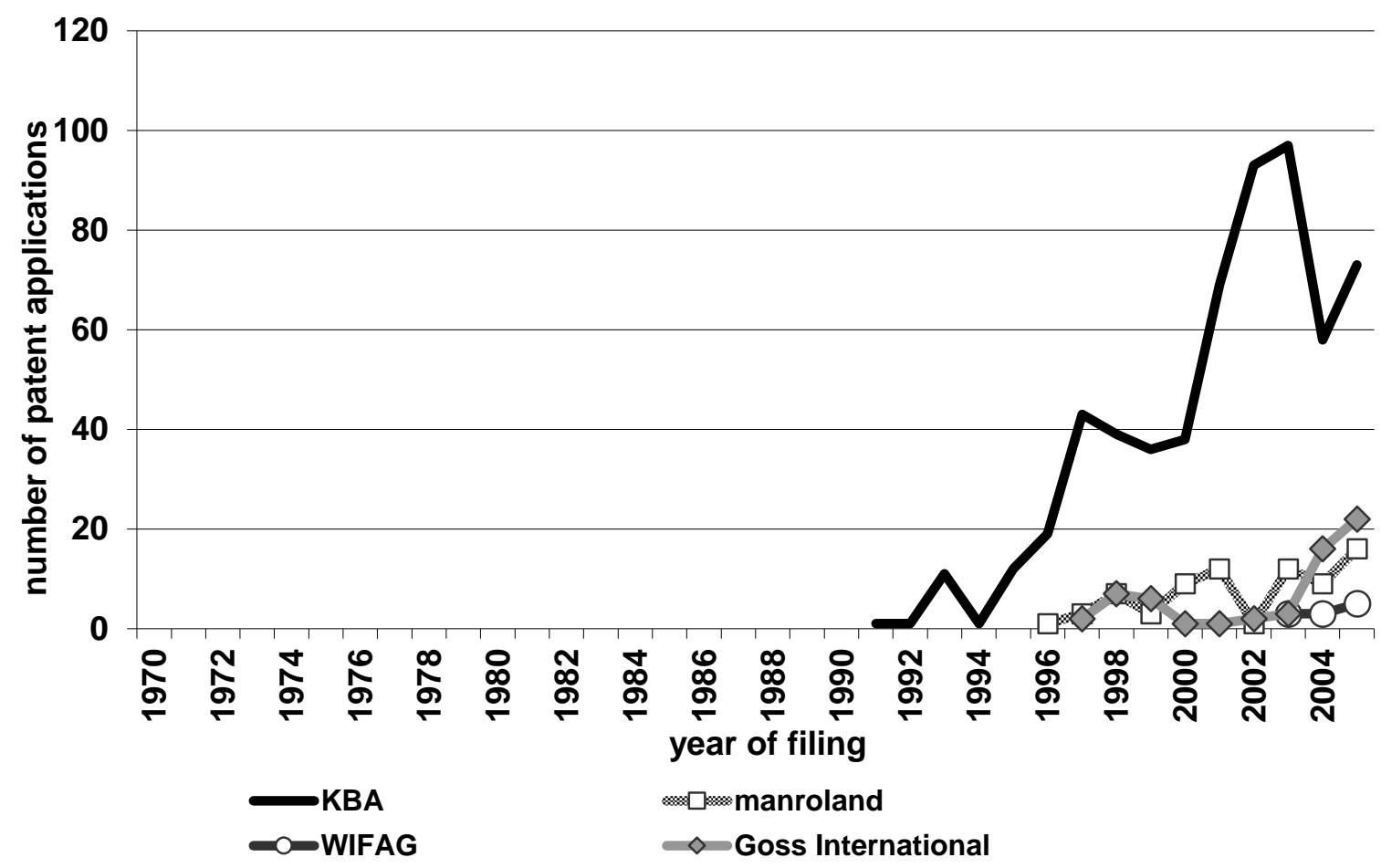




\section{GPTO applications}

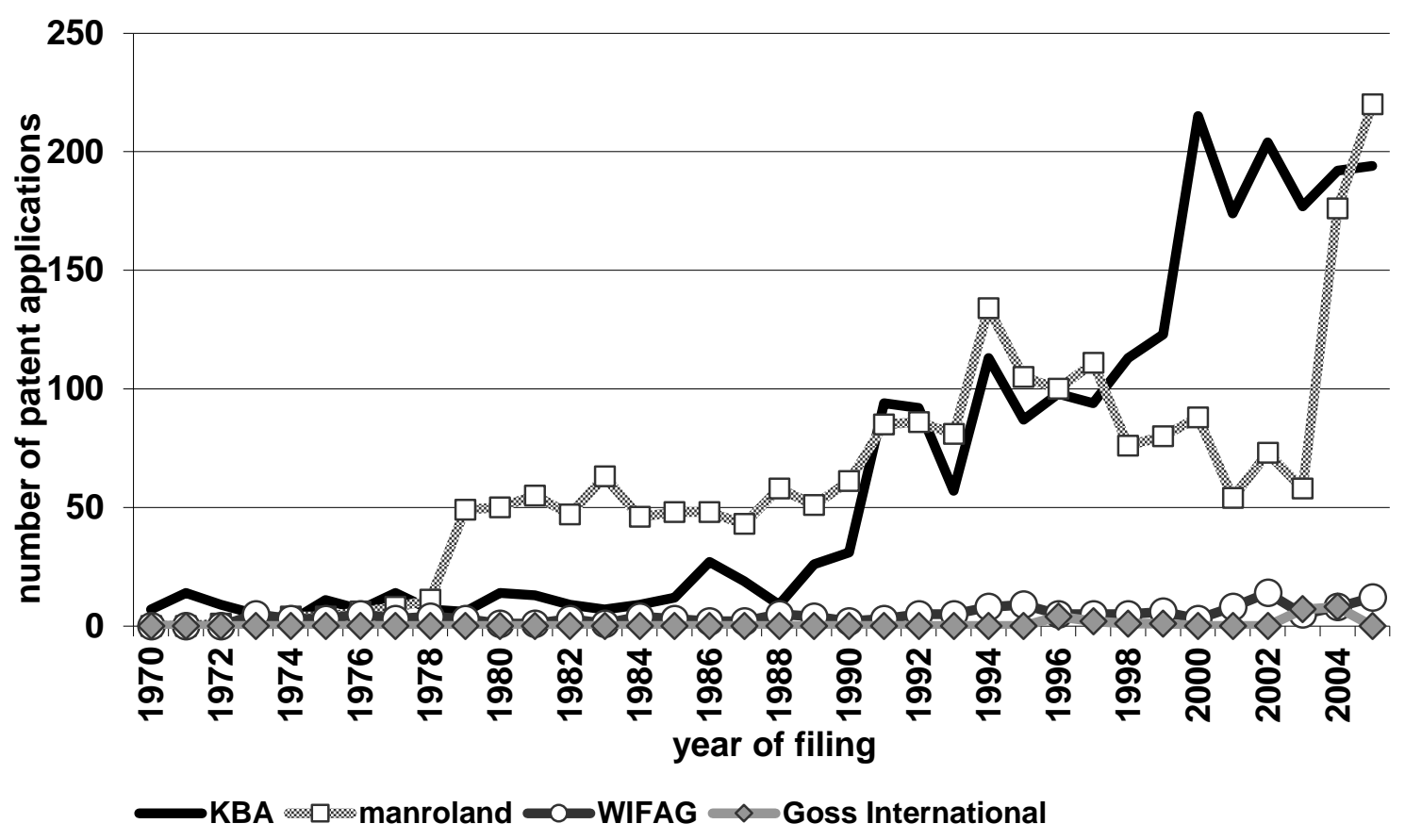

EPO applications

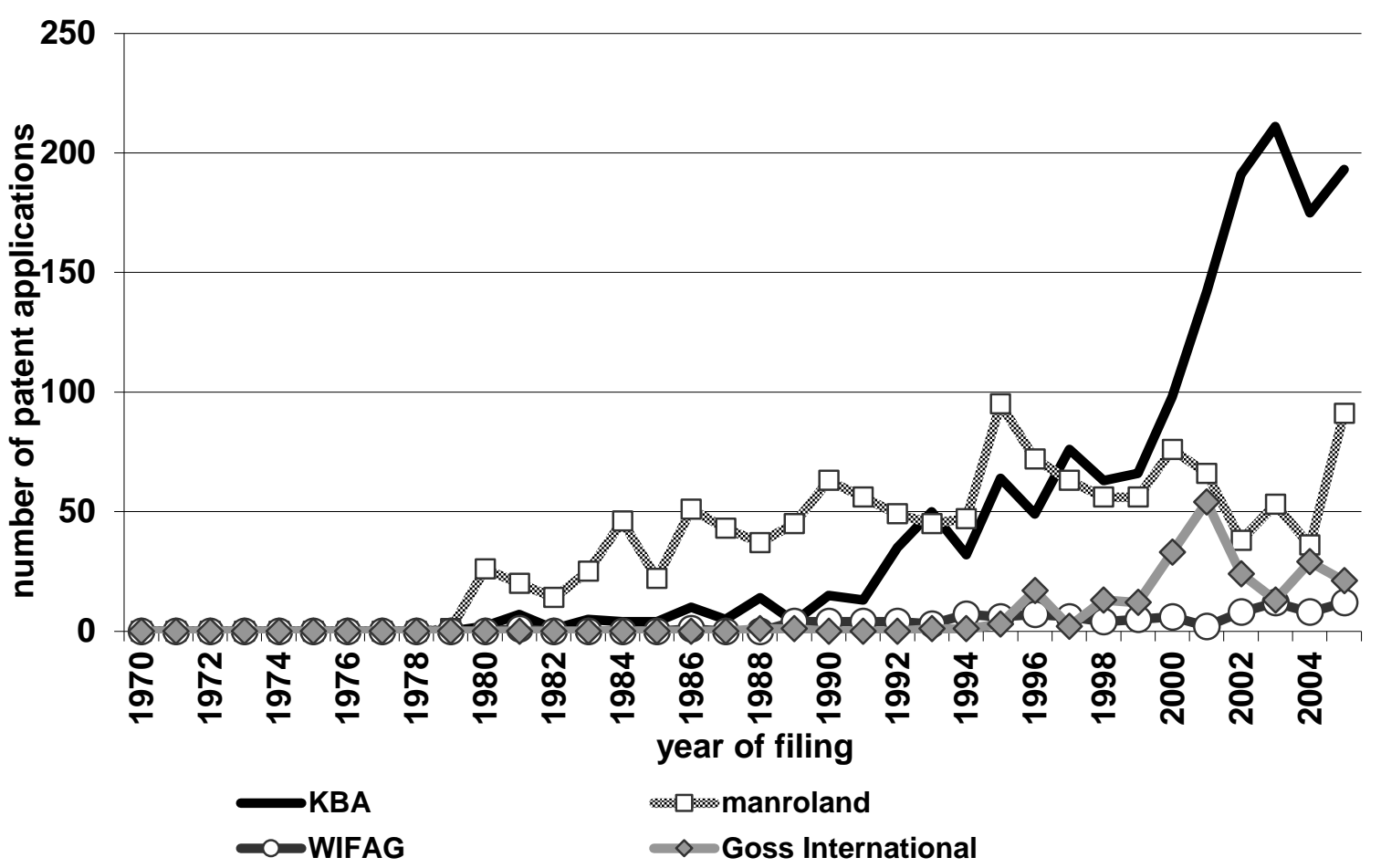




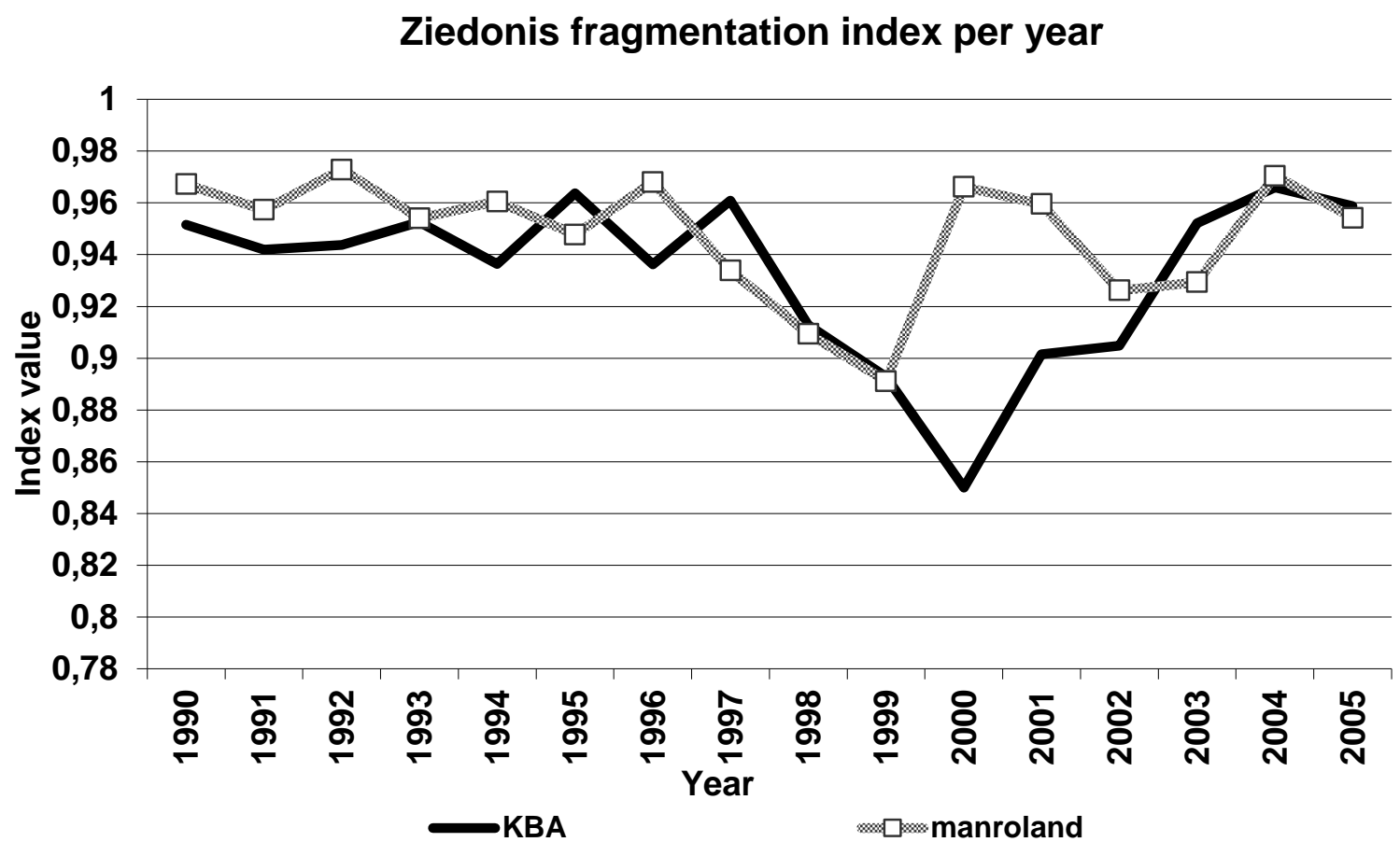

Ziedonis fragmentation index: We calculated the firm-specific index of fragmentation of patent ownership devised by Ziedonis (2004), on the basis of backward citations of European patent applications by KBA and Manroland. ${ }^{23}$ We find an average of the index of 0.93 for KBA and 0.95 for Manroland for the period between 1990 and 2005. However, although these values are quite high they should not be interpreted as an indicator of high fragmentation of patent ownership, for two reasons. First, the absolute number of backward citations per year underlying the index is low enough to allow incumbents to monitor their patent landscape (KBA: mean 191, median 95; Manroland: mean 72, median 68), in line with interview quotation (a). Second, the effective threat of patent infringement suits is determined not only by the likelihood of inadvertent infringement, but also by industry norms regarding litigation. Thus, even if our focal firms infringed on patents by parties outside their industry, this would not constitute a reason to embark on a defensive patent portfolio race as long as these potential infringements are not perceived as potential causes of litigation.

23 This index is similar in construction to the Herfindahl index of industry concentration, where a patent owner's share of backward citations in (say) KBA's patents in a given year corresponds to market share. The fragmentation index is calculated as unity minus the sum of the squared citation shares of all cited patent owners. Ziedonis (2004, p. 810) furthermore uses a correction factor, which is irrelevant in our context. 
Interestingly, KBA's index has a minimum in 2000, and Manroland's index exhibits a dip in 1999. However, analyzing which firms' patents were cited in KBA's and Manroland's patents, the total number of backward citations, and the total number of patent filings, we found no indication of a connection between the dips and the patent portfolio race we study. Also, the timing of the dips shows no systematic relationship with the timing of the two firms' patenting increases. 